In cooperation with the Texas State Soil and Water Conservation Board and U.S. Department of Agriculture, Natural Resources Conservation Service

\title{
Simulation of Flow and Effects of Best- Management Practices in the Upper Seco Creek Basin, South-Central Texas, 1991-98
}

Water-Resources Investigations Report 02-4249

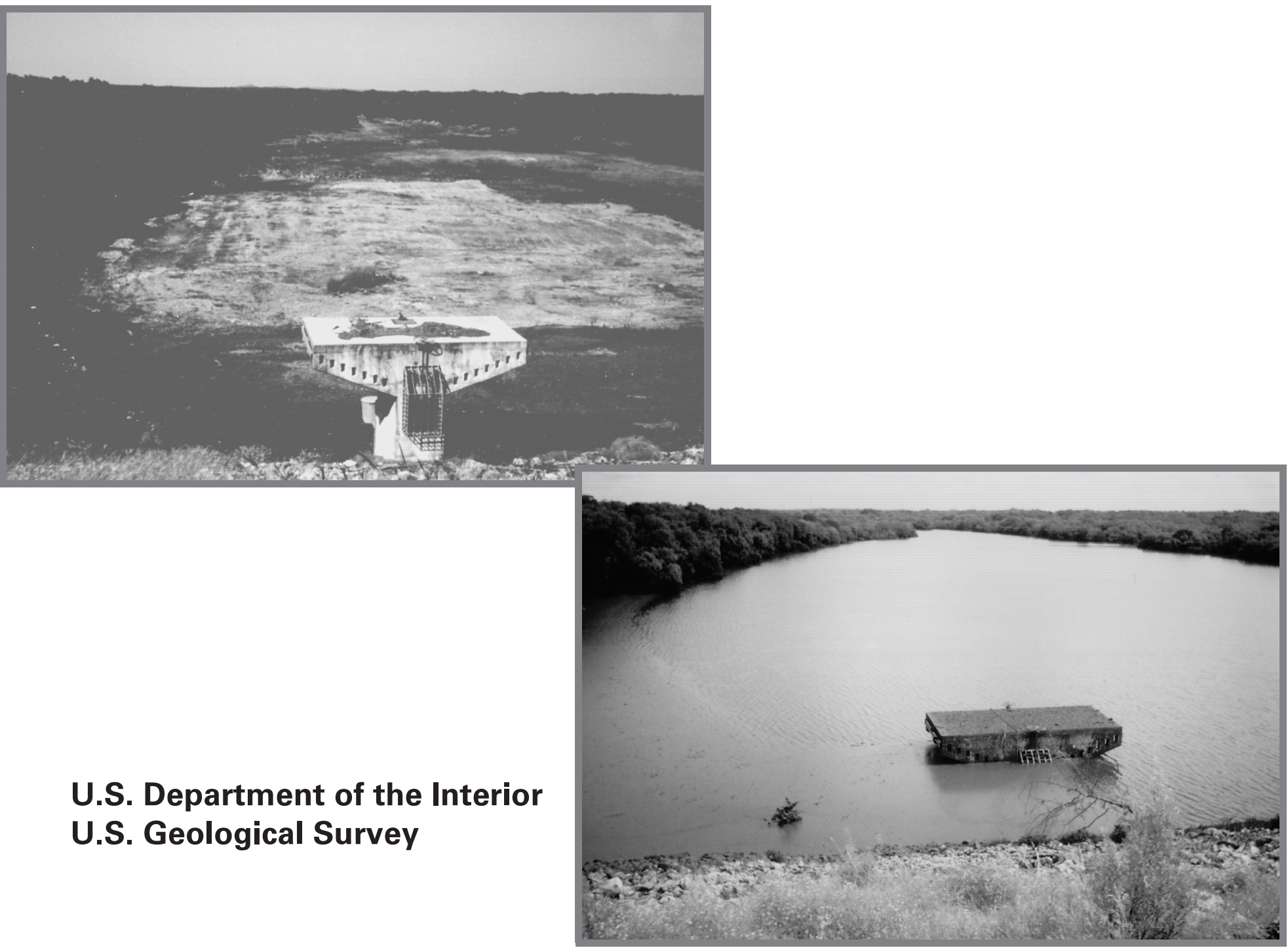




\section{Cover:}

Top: Empty Parkers Creek Reservoir (photograph by Jon R. Gilhousen, U.S. Geological Survey, December 4, 1991).

Bottom: Full Parkers Creek Reservoir (photograph by David S. Brown, U.S. Geological Survey, June 25, 1997). 
U.S. Department of the Interior

U.S. Geological Survey

\section{Simulation of Flow and Effects of Best- Management Practices in the Upper Seco Creek Basin, South-Central Texas, 1991-98}

By David S. Brown and Timothy H. Raines

U.S. GEOLOGICAL SURVEY

Water-Resources Investigations Report 02-4249

In cooperation with the Texas State Soil and Water Conservation Board and U.S. Department of Agriculture, Natural Resources Conservation Service 


\section{U.S. DEPARTMENT OF THE INTERIOR}

Gale A. Norton, Secretary

\section{U.S. GEOLOGICAL SURVEY}

Charles G. Groat, Director

Any use of trade, product, or firm names is for descriptive purposes only and does not imply endorsement by the U.S. Government.

For additional information write to

\section{District Chief}

U.S. Geological Survey

8027 Exchange Dr.

Austin, TX 78754-4733

E-mail: dc_tx@usgs.gov

Copies of this report can be purchased from

U.S. Geological Survey

Information Services

Box 25286

Denver, CO 80225-0286

E-mail: infoservices@usgs.gov 


\section{CONTENTS}

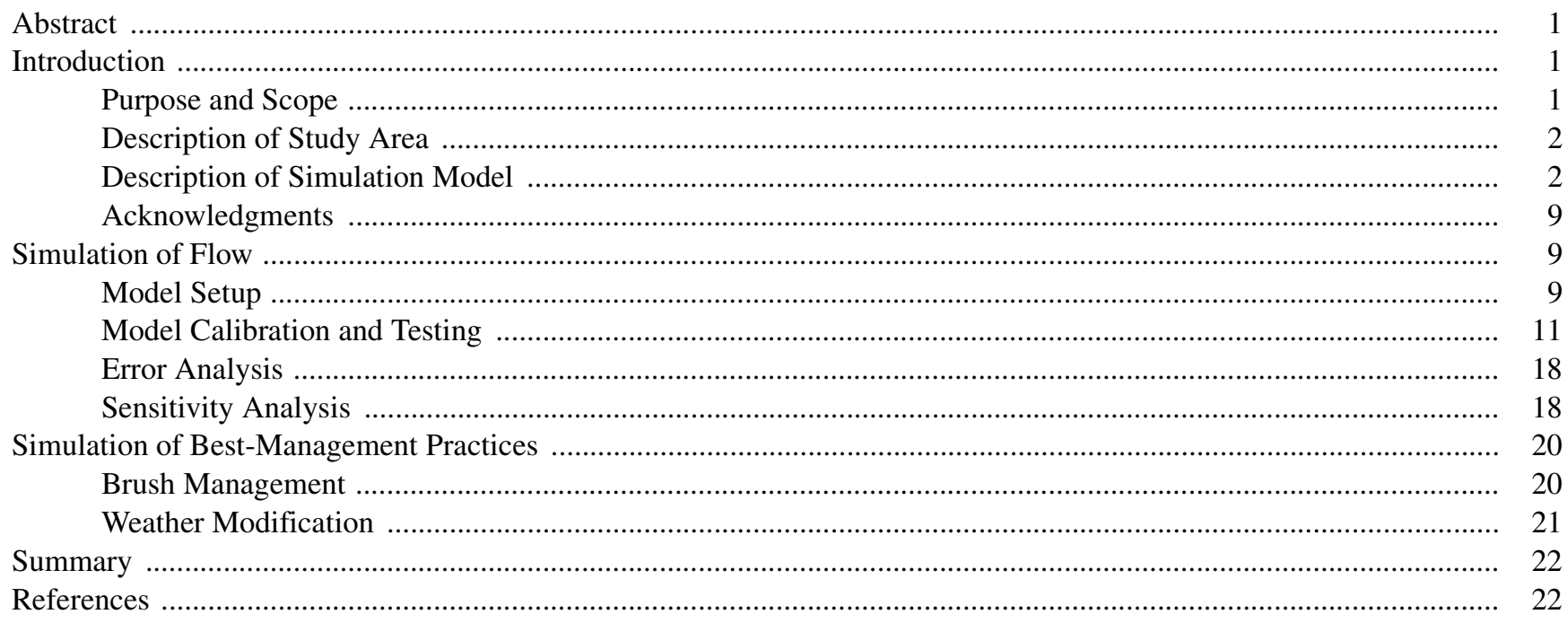

\section{FIGURES}

1-4. Maps showing:

1. Location of the upper Seco Creek Basin, south-central Texas ............................................................. 3

2. Data-collection network in the upper Seco Creek Basin ......................................................................... 4

3. Land use/cover in the upper Seco Creek Basin .................................................................................... 5

4. Surface and shallow subsurface geology in the upper Seco Creek Basin ................................................ 6

5-10. Graphs showing simulated and observed flow for:

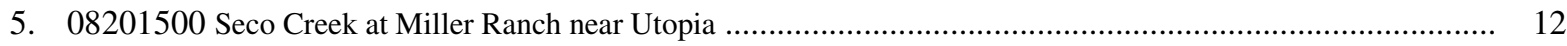

6. 08202450 Seco Creek Reservoir Inflow near Utopia ……................................................................... 12

7. 08202490 Seco Creek Reservoir Outflow near Utopia .......................................................................... 13

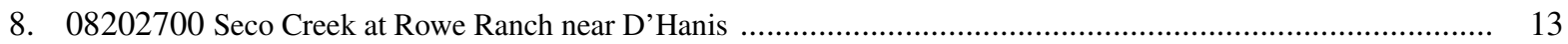

9. 08202790 Parkers Creek Reservoir Inflow near D'Hanis .......................................................................... 14

10. 08202810 Parkers Creek Reservoir Outflow near D'Hanis ........................................................................ 14

11. Graphs showing difference between simulated and observed monthly discharge for upper Seco Creek subbasins

\section{TABLES}

1. Daily rainfall, streamflow, and reservoir-content stations in the upper Seco Creek Basin ............................... 7

2. Process-related model parameters for the Hydrological Simulation Program—FORTRAN ............................ 8

3. Basin-related model parameters for the Hydrological Simulation Program_FORTRAN ............................... 8

4. Basin-related parameters for each gaged subbasin of the upper Seco Creek Basin ......................................... 10

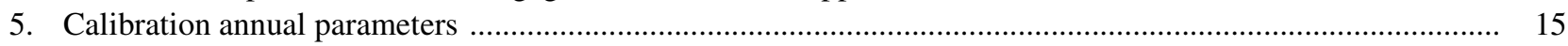

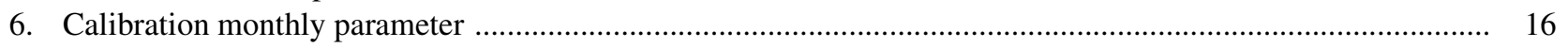

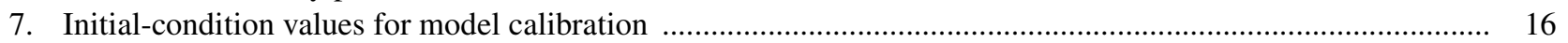

8. Summary of calibration and testing results for upper Seco Creek subbasins .................................................... 17

9. Summary of calibration and testing errors for upper Seco Creek subbasins .................................................. 17

10. Simulation results from a 5- to 6-percent reduction in evapotranspiration associated with brush management

11. Simulation results from a 10-percent increase in rainfall totals and intensities associated with weather modification 


\title{
Simulation of Flow and Effects of Best- Management Practices in the Upper Seco Creek Basin, South-Central Texas, 1991-98
}

\author{
By David S. Brown and Timothy H. Raines
}

\begin{abstract}
The Hydrological Simulation ProgramFORTRAN model was used to assess the effects of two best-management practices-brush management (removal of woody species locally known as cedar) and weather modification (rainfall enhancement) - on selected hydrologic processes in six subbasins that compose the upper Seco Creek Basin in south-central Texas. A parameter set for use with the model was developed to simulate surface-water-budget components for the six gaged subbasins.
\end{abstract}

Simulation of brush management, represented by decreases in simulated evapotranspiration of 5 to 6 percent, resulted in increases of 1 to 47 percent in annual runoff and increases of 14 to 48 percent in surface runoff for the six subbasins. Simulation of weather modification, represented by a 10-percent increase in rainfall totals and intensities, resulted in increases of 5 to 6 percent in evapotranspiration, increases of 2 to 92 percent in annual runoff, and increases of 36 to 101 percent in surface runoff.

Rainfall and runoff data for the study were collected during January 1, 1991-September 30, 1998. Data from 60 storms were used for the simulations. The model was calibrated with data from 33 storms (in two subbasins) and tested with data from 27 storms (in four subbasins). Twenty-one pervious land segments were defined for the study on the basis of geology and land cover. An error analysis and a sensitivity analysis were done on each subbasin, and the results were used to develop the final parameter set.

\section{INTRODUCTION}

In April 1990, the Seco Creek Water-Quality Demonstration Project was established as a State of Texas and U.S. Department of Agriculture cooperative project involving several State and Federal agencies, groups, and universities. The Seco Creek Water-Quality Demonstration Project is intended to demonstrate and transfer technology to farmers and ranchers and, thereby, encourage the implementation of agricultural best-management practices (BMPs) that will protect surface- and ground-water quality and potentially increase surface-water availability in the Seco Creek Basin. At least 60 different BMPs were implemented at 56 sites within the study area (Steffens and Wright, 1995). The BMPs included prescribed burning, installation of grass filter strips, and various agricultural management strategies for application and control of brush, crops, grazing, herbicides, nutrients, and pesticides. In 1991, the U.S. Geological Survey (USGS), in cooperation with the Texas State Soil and Water Conservation Board and the U.S. Department of Agriculture, Natural Resources Conservation Service, began a study to simulate flow for six selected subbasins in the upper Seco Creek Basin and to evaluate the effects of two BMPs on surface-water quantity.

\section{Purpose and Scope}

This report describes the use of a model to simulate selected hydrologic processes for six gaged subbasins in the upper Seco Creek Basin and presents an assessment of the effects on surface-water quantity in the basin of two BMPs, brush management and weather modification. Rainfall and runoff data collected from 60 storms during January 1, 1991-September 30, 1998, were used to calibrate and test the continuoussimulation model. Each subbasin was characterized using a minimum of 2 to a maximum of 19 unique pervious land segments that were defined on the basis of geology and land-cover types, and each subbasin was 
subdivided into a minimum of 1 to a maximum of 10 reaches for input to the simulation model. Twenty process-related parameters were defined for each land segment, and six basin-related parameters were defined for each subbasin. The calibrated model was used to evaluate the changes in surface-water quantity that are likely to result from brush management and weather modification.

\section{Description of Study Area}

The study area, upper Seco Creek Basin, is in south-central Texas (fig. 1). The Seco Creek Basin upstream from Seco Creek at Rowe Ranch (fig. 2) drains about 165 square miles $\left(\mathrm{mi}^{2}\right)$. The basin is divided into six major subbasins and contains two major reservoirs-Seco Creek Reservoir and Parkers Creek Reservoir (fig. 2). Both reservoirs are Edwards aquifer recharge structures. Recharge occurs when captured stormflows pond behind the dam and infiltrate the Edwards aquifer outcrop. Parkers Creek Reservoir also functions as a flood-control structure. The dam at Parkers Creek Reservoir is about 40 feet (ft) high, constructed of earthen material, and captures nearly all streamflow. A drop inlet structure and an earthen emergency spillway release streamflow only when the reservoir is filled to capacity during large runoffs. A $12-\mathrm{ft}-$ high, uncontrolled concrete ogee-crested dam at Seco Creek Reservoir diverts all flows less than about 350 to 400 cubic feet per second $\left(\mathrm{ft}^{3} / \mathrm{s}\right)$ into a sinkhole in the Edwards aquifer outcrop. Flows in excess of about 350 to $400 \mathrm{ft}^{3} / \mathrm{s}$ overtop the dam and pass downstream.

Thirteen rainfall stations, six streamflow-gaging stations, and one reservoir-content station are in the upper basin (table 1).

The study area is characterized by a moderate climate with hot, dry summers; warm, wet autumns; cool, dry winters; and warm, wet springs. Mean monthly temperature for the study area is 68 degrees Fahrenheit $\left({ }^{\circ} \mathrm{F}\right)$, with mean monthly temperatures ranging from $51^{\circ} \mathrm{F}$ in January to $84^{\circ} \mathrm{F}$ in July and August (Hydrosphere, 2000). Mean annual rainfall at Utopia (location shown in fig. 1) was about 32.6 inches (in.) (Hydrosphere, 2000). Rainfall is generated from frontal systems and convective heating. Frontal systems in the spring and fall produce moderate- to high-intensity, long-duration storms that generally result in peak streamflows for the year. Convective thunderstorms, that occur mostly in the summer, produce widely scattered, high-intensity, short-duration storms.
Basin slopes vary from steep (typically 0.08 to $0.12 \mathrm{foot} /$ foot $[\mathrm{ft} / \mathrm{ft}])$ in the upper part of the basin to moderate (typically 0.01 to $0.08 \mathrm{ft} / \mathrm{ft}$ ) in the lower part of the upper basin.

Major land uses are ranching and farming (rangeland 88 percent; cropland 9.3 percent) (Steffens and Wright, 1995) (fig. 3). The predominant land cover, rangeland, is used for grazing cattle, goats, deer, and exotic game animals; whereas, cropland is used for growing corn, cotton, milo, and wheat.

On the surface and in the shallow subsurface, the northern part of the study area (essentially the upper three subbasins) comprises rocks of the Trinity aquifer, primarily Glen Rose Limestone. The southern part of the study area (essentially the lower three subbasins) comprises rocks of the Edwards aquifer, primarily Devils River Formation, and rocks of several formations that are considered local shallow aquifers or confining units of the Edwards aquifer (fig. 4). The area where the Edwards aquifer (Devils River Formation) crops out delineates the Edwards aquifer recharge zone in the study area.

\section{Description of Simulation Model}

The Hydrological Simulation ProgramFORTRAN (HSPF) (Bicknell and others, 1997) is a continuous-simulation model that uses a conceptual framework to represent hydrologic processes including infiltration, evaporation, interception storage, surface runoff, interflow, and base flow on a pervious land segment (PERLND) and to represent retention storage and surface runoff on an impervious land segment (IMPLND). Each user-defined land segment represents its own unique hydrologic response system on the basis of soils, geology and land cover, basin slope, or other basin characteristics. These land segments do not need to be contiguous. The runoff from each land segment is moved through a system of reaches or reservoirs using storage routing.

The HSPF model uses input from three types of data: time series, process-related model parameters, and basin-related model parameters. Continuous time series of precipitation and potential evaporation are needed for model simulations. Point-precipitation data, measured by rain gages, are assumed to be uniform over a land segment. Potential evaporation data can be estimated from measured pan evaporation or can be computed using minimum and maximum temperatures. Time series of measured runoff are used for model calibration and testing. 


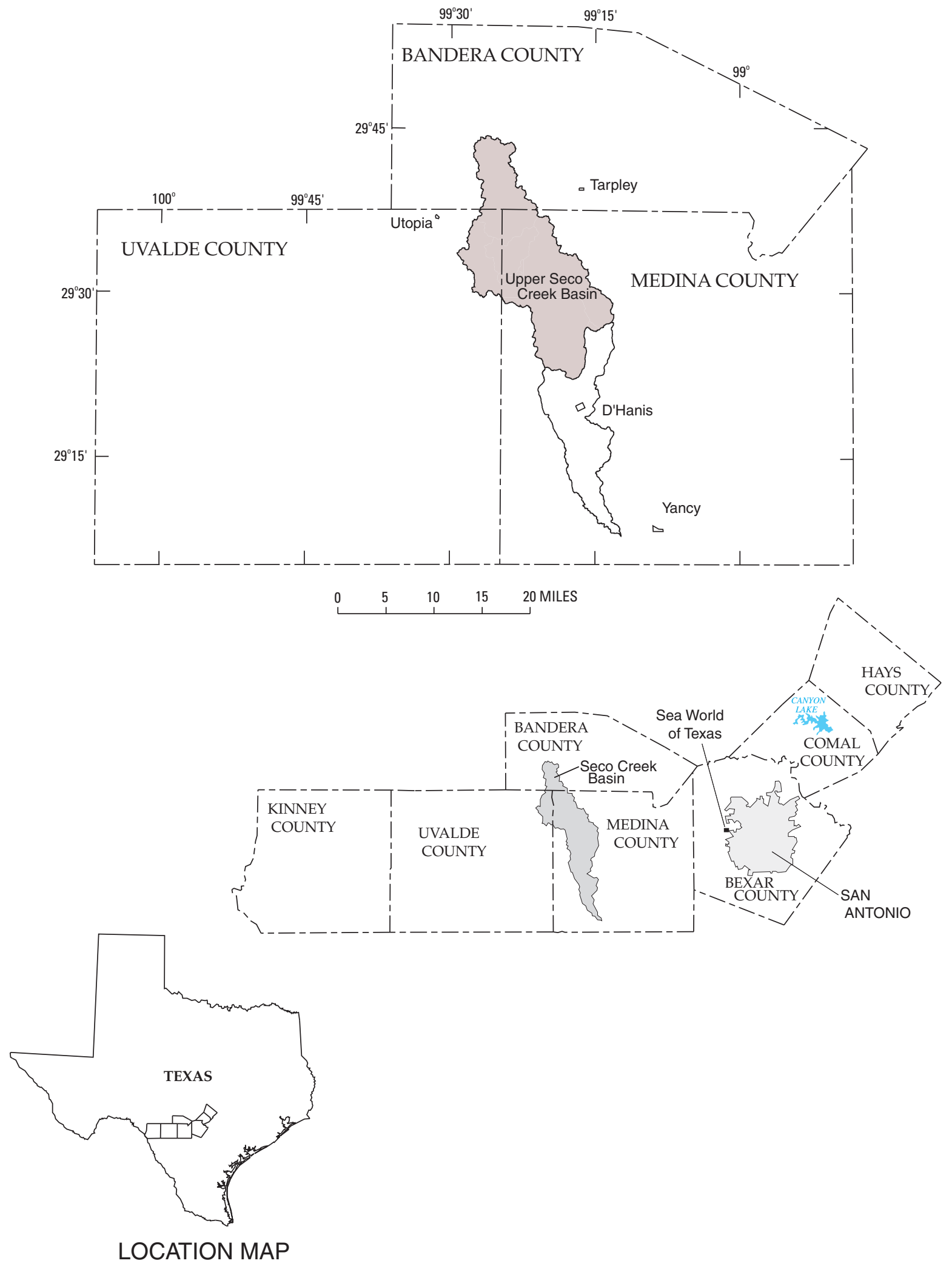

Figure 1. Location of the upper Seco Creek Basin, south-central Texas. 


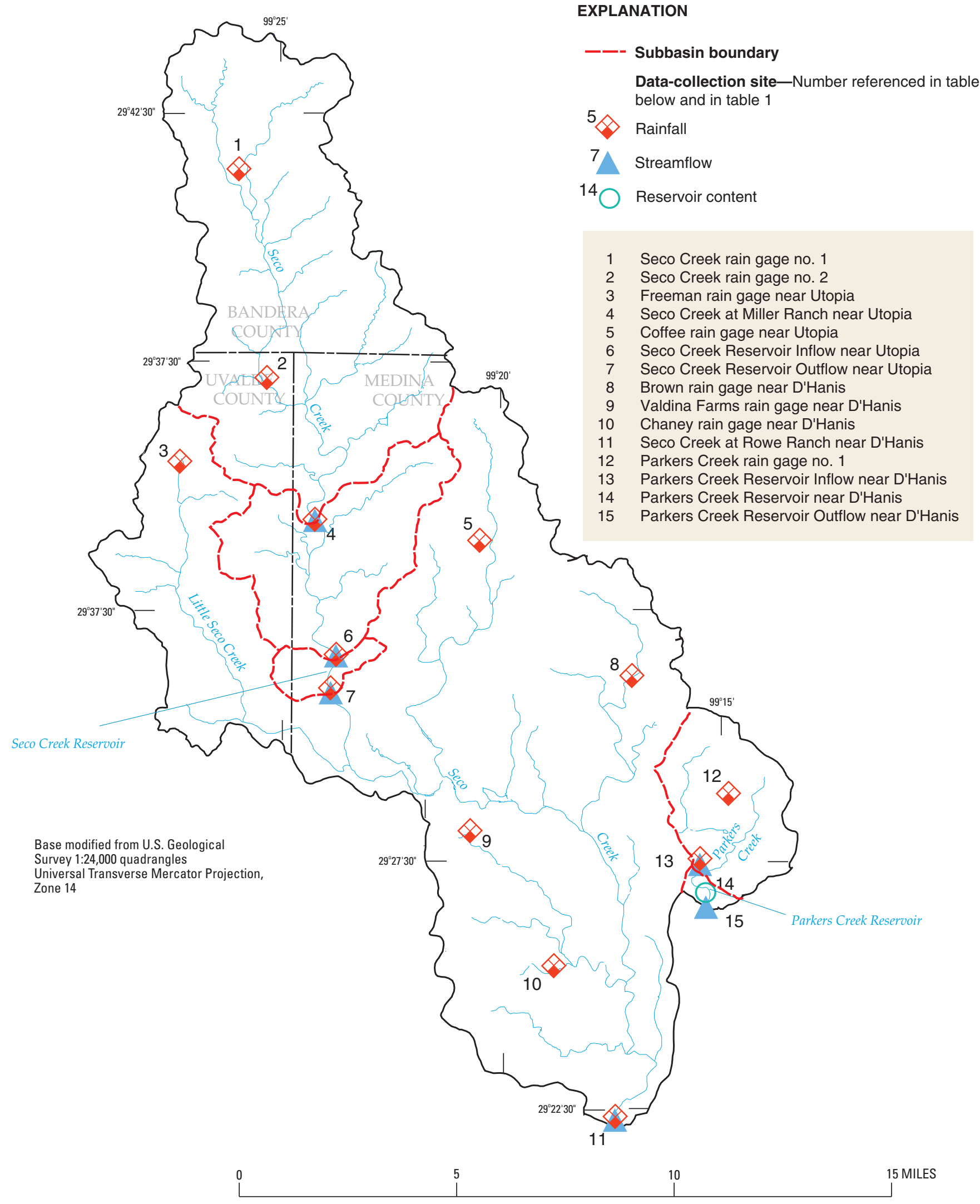

Figure 2. Data-collection network in the upper Seco Creek Basin. 


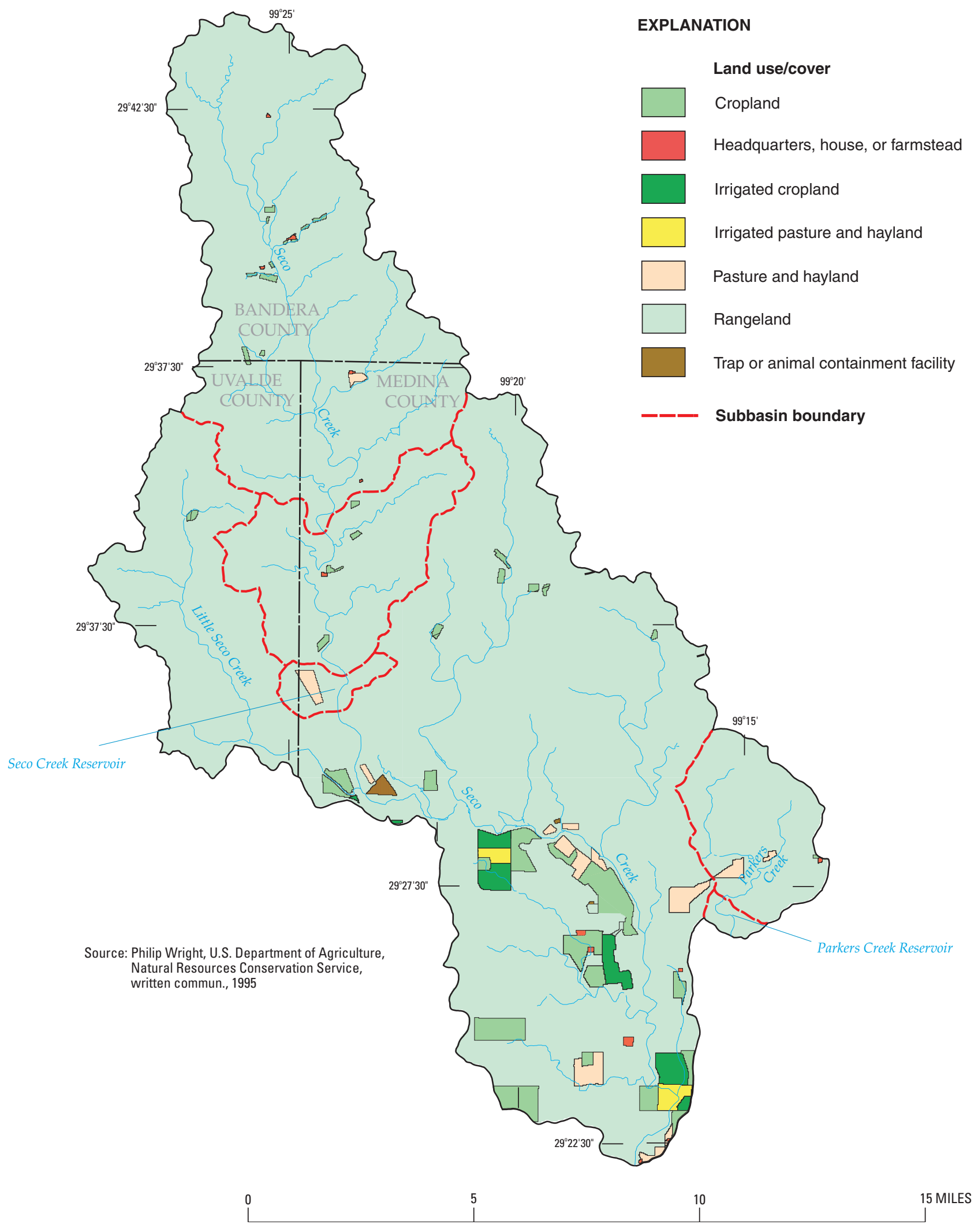

Figure 3. Land use/cover in the upper Seco Creek Basin. 


\section{EXPLANATION}

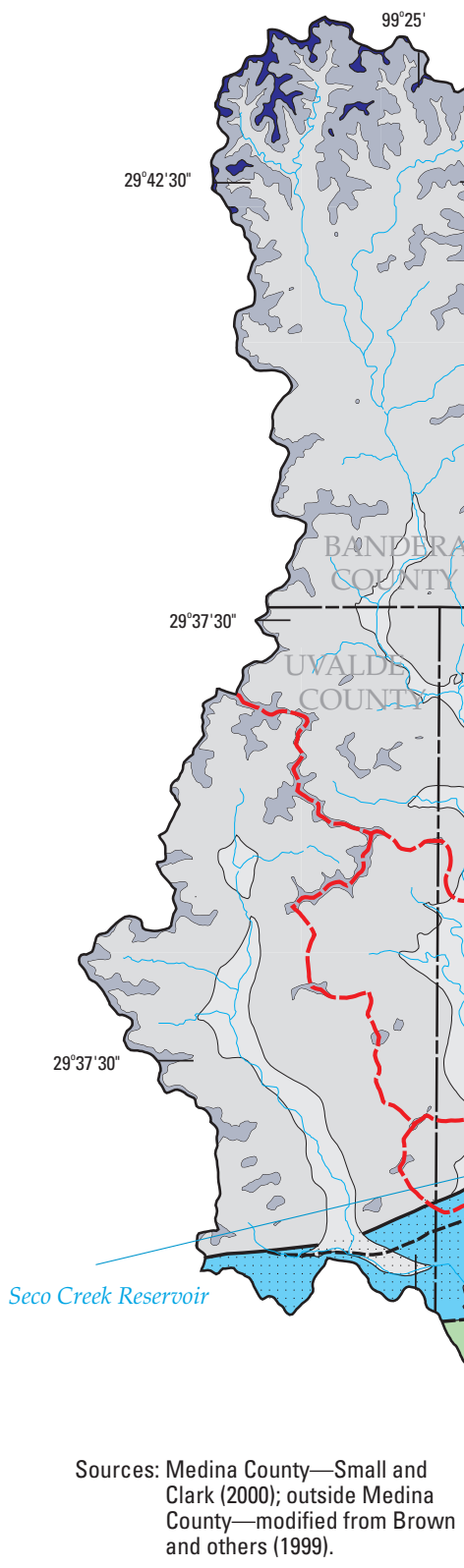

Edwards aquifer recharge zone

\section{Geology}

Alluvium

Leona Formation

Uvalde Gravel

Escondido Formation

Anacacho Limestone

Austin Group

Eagle Ford Group

Buda Limestone

Del Rio Clay

Segovia Formation and Devils River Formation

Fort Terrett Formation and Devils River Formation

Glen Rose Limestone (upper confining unit)

\section{Subbasin boundary}

Primary fault

------ Inferred fault 
Table 1. Daily rainfall, streamflow, and reservoir-content stations in the upper Seco Creek Basin $\left[\mathrm{mi}^{2}\right.$, square miles; --, not applicable]

\begin{tabular}{|c|c|c|c|c|c|c|}
\hline $\begin{array}{l}\text { Site } \\
\text { no. } \\
\text { (fig. 2) }\end{array}$ & $\begin{array}{c}\text { Station } \\
\text { no. }\end{array}$ & Station name & Latitude & Longitude & $\begin{array}{c}\text { Drainage } \\
\text { area } \\
\left(\mathrm{mi}^{2}\right)\end{array}$ & $\begin{array}{c}\text { Period of } \\
\text { record } \\
\text { (water } \\
\text { years }^{1} \text { ) }\end{array}$ \\
\hline \multicolumn{7}{|c|}{ Rainfall } \\
\hline 1 & 2941250992554 & Seco Creek rain gage no. 1 & $29^{\circ} 41^{\prime} 25^{\prime \prime}$ & $99^{\circ} 25^{\prime} 54^{\prime \prime}$ & -- & 1991-98 \\
\hline 2 & 2937170992513 & Seco Creek rain gage no. 2 & $29^{\circ} 37^{\prime} 17^{\prime \prime}$ & $99^{\circ} 25^{\prime} 13^{\prime \prime}$ & -- & 1991-98 \\
\hline 3 & 2935500992723 & Freeman rain gage near Utopia & $29^{\circ} 35^{\prime} 50^{\prime \prime}$ & $99^{\circ} 27^{\prime} 23^{\prime \prime}$ & -- & 1994-98 \\
\hline 4 & 08201500 & Seco Creek at Miller Ranch near Utopia & $29^{\circ} 34^{\prime} 23^{\prime \prime}$ & $99^{\circ} 24^{\prime} 10^{\prime \prime}$ & -- & $1988-2000$ \\
\hline 5 & 2937550992019 & Coffee rain gage near Utopia & $29^{\circ} 33^{\prime} 55^{\prime \prime}$ & $99^{\circ} 20^{\prime} 19^{\prime \prime}$ & -- & 1994-98 \\
\hline 6 & 08202450 & Seco Creek Reservoir Inflow near Utopia & $29^{\circ} 31^{\prime} 34^{\prime \prime}$ & $99^{\circ} 23^{\prime} 42^{\prime \prime}$ & -- & 1991-98 \\
\hline 7 & 08202490 & Seco Creek Reservoir Outflow near Utopia & $29^{\circ} 30^{\prime} 58^{\prime \prime}$ & $99^{\circ} 23^{\prime} 51^{\prime \prime}$ & -- & 1991-97 \\
\hline 8 & 2931150991651 & Brown rain gage near D'Hanis & $29^{\circ} 31^{\prime} 15^{\prime \prime}$ & $99^{\circ} 16^{\prime} 51^{\prime \prime}$ & -- & 1995-98 \\
\hline 9 & 2928080992030 & Valdina Farms rain gage near D'Hanis & $29^{\circ} 28^{\prime} 08^{\prime \prime}$ & $99^{\circ} 20^{\prime} 30^{\prime \prime}$ & -- & 1994-98 \\
\hline 10 & 2925270991837 & Chaney rain gage near D'Hanis & $29^{\circ} 25^{\prime} 27^{\prime \prime}$ & $99^{\circ} 18^{\prime} 37^{\prime \prime}$ & -- & 1994-98 \\
\hline 11 & 08202700 & Seco Creek at Rowe Ranch near D'Hanis & $29^{\circ} 22^{\prime} 14^{\prime \prime}$ & $99^{\circ} 17^{\prime} 15^{\prime \prime}$ & -- & 1994-98 \\
\hline 12 & 2928480991442 & Parkers Creek rain gage no. 1 & $29^{\circ} 28^{\prime} 48^{\prime \prime}$ & $99^{\circ} 14^{\prime} 42^{\prime \prime}$ & -- & 1991-98 \\
\hline 13 & 08202790 & Parkers Creek Reservoir Inflow near D'Hanis & $29^{\circ} 27^{\prime} 27^{\prime \prime}$ & $99^{\circ} 15^{\prime} 16^{\prime \prime}$ & -- & $1991-97$ \\
\hline \multicolumn{7}{|c|}{ Streamflow } \\
\hline 4 & 08201500 & Seco Creek at Miller Ranch near Utopia & $29^{\circ} 34^{\prime} 23^{\prime \prime}$ & $99^{\circ} 24^{\prime} 10^{\prime \prime}$ & 45.0 & $1961-2001$ \\
\hline 6 & 08202450 & Seco Creek Reservoir Inflow near Utopia & $29^{\circ} 31^{\prime} 34^{\prime \prime}$ & $99^{\circ} 23^{\prime} 42^{\prime \prime}$ & 59.4 & 1991-98 \\
\hline 7 & 08202490 & Seco Creek Reservoir Outflow near Utopia & $29^{\circ} 30^{\prime} 58^{\prime \prime}$ & $99^{\circ} 23^{\prime} 51^{\prime \prime}$ & 61.4 & $1991-97$ \\
\hline 11 & 08202700 & Seco Creek at Rowe Ranch near D'Hanis & $29^{\circ} 22^{\prime} 14^{\prime \prime}$ & $99^{\circ} 17^{\prime} 15^{\prime \prime}$ & 165 & $1961-2001$ \\
\hline 13 & 08202790 & Parkers Creek Reservoir Inflow near D’Hanis & $29^{\circ} 27^{\prime} 27^{\prime \prime}$ & $99^{\circ} 15^{\prime} 16^{\prime \prime}$ & 9.40 & 1991-97 \\
\hline 15 & 08202810 & Parkers Creek Reservoir Outflow near D’Hanis & $29^{\circ}--^{\prime--"}$ & $99^{\circ}--^{\prime--"}$ & 10.1 & $1991-97$ \\
\hline \multicolumn{7}{|c|}{ Reservoir content } \\
\hline 14 & 08202800 & Parkers Creek Reservoir near D'Hanis & $29^{\circ} 26^{\prime} 42^{\prime \prime}$ & $99^{\circ} 15^{\prime} 09^{\prime \prime}$ & 10.1 & $1991-97$ \\
\hline
\end{tabular}

${ }^{1}$ A water year is the 12-month period October 1-September 30, designated by the year in which it ends.

The 20 process-related model parameters listed in table 2 represent the physical processes of soil infiltration, soil moisture storage, evapotranspiration (ET), interception storage of plants, interflow recession, ground-water recession, and surface runoff for each land segment. The process-related model parameters for each land segment are adjusted to calibrate the model. The following parameters can be varied by month to account for seasonal variations: interception storage capacity (CEPSC), interflow inflow (INTFW), interflow recession rate (IRC), lower-zone ET (LZETP), Manning's n for assumed overland flow plane (NSUR), and upper-zone nominal storage (UZSN). The HSPF user's manual (Bicknell and others, 1997) provides a more complete description of each parameter.

The six basin-related model parameters listed in table 3 define the areal extent of each land segment, the reach length, and a table of values (FTABLE) of surface area, volume, and discharge as a function of depth for each reach of the subbasin. These parameters represent the physical characteristics of each reach of a subbasin and generally remain unchanged during calibration and testing of the model.

One set of process-related parameters was developed using uniform parameters for each land segment. Annual, monthly, and initial model conditions were standardized for each of the six gaged subbasins. 
Table 2. Process-related model parameters for the Hydrological Simulation Program—FORTRAN

[--, none; ET, evapotranspiration]

\begin{tabular}{|c|c|c|c|c|c|}
\hline Parameter & Description $^{1}$ & Default & Minimum & Maximum & Units \\
\hline AGWS & Initial active ground-water storage & -- & 0 & 100 & inches \\
\hline AGWETP & Available ET satisfied by active ground water & 0 & 0 & 1.0 & -- \\
\hline AGWRC & Active ground-water recession rate & -- & .001 & .999 & per day \\
\hline BASETP & Available ET satisfied by base flow & 0 & 0 & 1.0 & -- \\
\hline CEPSC & Interception storage capacity & 0 & 0 & 10.0 & inches \\
\hline DEEPFR & Fraction of inflow that enters inactive ground water & 0 & 0 & 1.0 & -- \\
\hline INFEXP & Infiltration equation exponent & 2.0 & 0 & 10.0 & -- \\
\hline INFILD & Ratio of maximum to mean infiltration capacities & 2.0 & 1.0 & 2.0 & -- \\
\hline INFILT & Index to infiltration capacity of soil & -- & .0001 & 100.0 & inches per hour \\
\hline INTFW & Interflow inflow & -- & 0 & -- & -- \\
\hline IRC & Interflow recession rate & -- & $1.0^{-30}$ & .999 & per day \\
\hline KVARY & Nonlinear modifier of ground-water recession rate & 0 & 0 & -- & per inch \\
\hline LSUR & Length of assumed overland flow plane & -- & 1.0 & -- & feet \\
\hline LZETP & Available ET satisfied by lower-zone ground water & 0 & 0 & .999 & -- \\
\hline LZS & Initial lower-zone storage & .001 & .001 & -- & inches \\
\hline LZSN & Lower-zone nominal storage & -- & .01 & 100.0 & inches \\
\hline NSUR & Manning's $\mathrm{n}$ for assumed overland flow plane & .1 & .001 & 1.0 & -- \\
\hline SLSUR & Slope of assumed overland flow plane & -- & .000001 & 10.0 & feet per foot \\
\hline UZS & Initial upper-zone storage & .001 & .001 & 100.0 & inches \\
\hline UZSN & Upper-zone nominal storage & -- & .01 & 10.0 & inches \\
\hline
\end{tabular}

${ }^{1}$ The user's manual for Hydrological Simulation Program-FORTRAN (Bicknell and others, 1997) provides a more complete description of each parameter.

Table 3. Basin-related model parameters for the Hydrological Simulation Program-FORTRAN

[PERLND, pervious land segment; IMPLND, impervious land segment; FTABLE, table of depth, surface area, volume, and discharge for each reach]

\begin{tabular}{|c|c|}
\hline Parameter & $\begin{array}{l}\text { Description } \\
\quad \text { (unit) }\end{array}$ \\
\hline AREA & Drainage area of each PERLND or IMPLND (acres) \\
\hline LEN & Reach length (miles) \\
\hline DEPTH & FTABLE depth (feet) \\
\hline SAREA & FTABLE surface area (acres) \\
\hline VOL & FTABLE volume (acre-feet) \\
\hline DISCH & FTABLE discharge (cubic feet per second) \\
\hline
\end{tabular}

${ }^{1}$ The user's manual for Hydrological Simulation Program-FORTRAN (Bicknell and others, 1997) provides a more complete description of each parameter. 
Geology and land-cover data were merged to create the land segments. Regionalization (a process of iterative simulations that are conducted within and between subbasins during the calibration process to optimize parameter values) of the parameter set was done, which decreased model accuracy somewhat for individual subbasins but increased overall model accuracy. The parameter set was assumed to represent the average subbasin conditions for the simulation periods.

Error and sensitivity analyses were done to qualify the accuracy of the model and the effect that BMPs might have had on the model results. The calibration of the model was facilitated by a computer program developed by Lumb and others (1994) that provided graphics, error statistics, and guidance on which parameters to adjust to reduce the differences between simulated and measured data.

\section{Acknowledgments}

Special thanks are extended to Phillip Wright and Tom Fillinger, U.S. Department of Agriculture, Natural Resources Conservation Service, for assisting with data-collection activities and providing invaluable insight regarding the Seco Creek Basin. The authors also thank the landowners for graciously allowing access to their property.

\section{SIMULATION OF FLOW}

Six selected subbasins in the upper Seco Creek Basin were modeled to simulate surface-water-budget components. A set of process-related model parameters was developed from calibration of data collected from the Seco Creek at Miller Ranch and Parkers Creek Reservoir Inflow subbasins. The parameter set was tested spatially on the Seco Creek Reservoir Inflow and Outflow, Seco Creek at Rowe Ranch, and Parkers Creek Reservoir Outflow subbasins. Data used in the calibration process were collected during July 1, 1992September 30, 1998, and January 1, 1991-June 19, 1997, for Seco Creek at Miller Ranch and Parkers Creek Reservoir Inflow subbasins, respectively. Testing of the model parameter set was done using data collected during July 1, 1992-September 30, 1998, and July 1, 1992June 21, 1997, for Seco Reservoir Inflow and Outflow subbasins; July 1, 1992-June 19, 1997, for Seco Creek at Rowe Ranch subbasin; and January 1, 1991-June 19, 1997, for Parkers Creek Reservoir Outflow subbasin. An error analysis was done to identify sources of error that were not explained by the simulation model. A sen- sitivity analysis was done to identify which parameters had the greatest effect on simulation results.

\section{Model Setup}

Rainfall and streamflow-gaging stations (fig. 2; table 1) were installed to collect data needed for calibration and testing of the continuous-simulation model. Rainfall data were distributed over a land segment using the Theisen-weighting method (Maidment, 1993). Rainfall was measured with a network of six float rain-gage stations (1991-95) and 12 tipping-bucket rain-gage stations (1994-98) in the six gaged subbasins. Some rainfall data were lost because of instrumentation failure during the study period and were estimated using the rainfall measured at nearby stations and best professional judgment. Streamflow data used in this report were collected at six stations during 1991-98. Daily pan-evaporation data measured at Canyon Lake (located in Comal County; fig. 1) were used as representative of the study area. Missing pan-evaporation data were estimated on the basis of regression analysis of data from Canyon Lake and Sea World of Texas located in San Antonio (fig. 1).

Geographic information system (GIS) coverages of land cover were provided by the U.S. Department of Agriculture (fig. 3). Geology coverages (fig. 4) were developed by the USGS from field mapping of geologic outcrops, previous studies, and a well inventory. A total of 21 PERLNDs were developed for this model on the basis of the intersection of geology and land cover (table 4).

The main stream channel for each of the six gaged subbasins was subdivided into 1 to 10 reaches. Reach lengths were measured from USGS 1:100,000 hydrography coverages. A channel cross section was surveyed for each of four reaches (Seco Creek at Miller Ranch, Seco Reservoir Inflow, Seco Reservoir Outflow, and Parkers Creek Reservoir Inflow) to compute the FTABLE values. A channel cross section was estimated for each reach of the Seco Creek at Rowe Ranch and Parkers Creek Reservoir Outflow subbasins because access was limited. The surface area as a function of depth was computed by multiplying the average channel width by the reach length. The volume as a function of depth was computed by multiplying the average cross-sectional area by the reach length. Discharge as a function of depth was determined from (1) the 
Table 4. Basin-related parameters for each gaged subbasin of the upper Seco Creek Basin

[Land segments characterized and designated by 2-digit geology/land-cover descriptor: 01, Devils River Formation rangeland; 02, Buda Limestone rangeland; 03, Devils River Formation pasture/hay; 04, Eagle Ford Group pasture/hay; 05, Eagle Ford Group rangeland; 06, Austin Group rangeland; 07, Del Rio Clay rangeland; 08, Glen Rose Limestone rangeland; 09, Glen Rose Limestone pasture/hay; 10, alluvium pasture/hay; 11, alluvium rangeland; 12, Fort Terrett Formation rangeland; 13, Segovia Formation rangeland; 17, Leona Formation cropland; 18, Leona Formation rangeland; 20, Leona Formation irrigated cropland; 24 Leona Formation irrigated pasture/hay; 25, Leona Formation pasture/hay; 33, Anacacho Limestone rangeland; 34, Austin Group cropland; 37, Uvalde Gravel rangeland

PERLND, pervious land segment; IMPLND, impervious land segment; NRECH, number of reaches; LEN, reach lengths; mi, miles; FTABLE, table of depths (DEPTH), surface areas (SAREA), volumes (VOL), discharges (DISCH), and channel losses (CHNLOSS) for reaches; ft, feet; acre-ft, acre-feet; $\mathrm{ft}^{3} / \mathrm{s}$, cubic feet per second]

\begin{tabular}{|c|c|c|c|c|c|c|}
\hline \multirow[b]{2}{*}{ Parameter $^{1}$} & \multicolumn{6}{|c|}{ Subbasin } \\
\hline & $\begin{array}{l}\text { Miller } \\
\text { Ranch }\end{array}$ & $\begin{array}{l}\text { Seco Creek } \\
\text { Reservoir } \\
\text { Inflow }\end{array}$ & $\begin{array}{c}\text { Seco Creek } \\
\text { Reservoir } \\
\text { Outflow }\end{array}$ & $\begin{array}{l}\text { Rowe } \\
\text { Ranch }\end{array}$ & $\begin{array}{c}\text { Parkers Creek } \\
\text { Reservoir } \\
\text { Inflow }\end{array}$ & $\begin{array}{c}\text { Parkers Creek } \\
\text { Reservoir } \\
\text { Outflow }\end{array}$ \\
\hline \multicolumn{7}{|l|}{$\begin{array}{l}\text { PERLND AREA (acres) } \\
\text { (a) }\end{array}$} \\
\hline 01 & 0 & 0 & 351 & 24,198 & 4,902 & 5,310 \\
\hline 02 & 0 & 0 & 0 & 2,227 & 142 & 142 \\
\hline 03 & 0 & 0 & 0 & 52 & 70 & 70 \\
\hline 04 & 0 & 0 & 0 & 16 & 49 & 49 \\
\hline 05 & 0 & 0 & 0 & 489 & 44 & 44 \\
\hline 06 & 0 & 0 & 0 & 5,107 & 47 & 47 \\
\hline 07 & 0 & 0 & 0 & 162 & 750 & 805 \\
\hline 08 & 20,080 & 27,383 & 27,928 & 42,855 & 0 & 0 \\
\hline 09 & 0 & 0 & 82 & 194 & 0 & 0 \\
\hline 10 & 0 & 0 & 52 & 52 & 0 & 0 \\
\hline 11 & 1,428 & 2,921 & 3,148 & 4,504 & 0 & 0 \\
\hline 12 & 6,933 & 7,325 & 7,325 & 9,662 & 0 & 0 \\
\hline 13 & 393 & 393 & 393 & 393 & 0 & 0 \\
\hline 17 & 0 & 0 & 0 & 2,105 & 0 & 0 \\
\hline 18 & 0 & 0 & 0 & 8,591 & 0 & 0 \\
\hline 20 & 0 & 0 & 0 & 1,020 & 0 & 0 \\
\hline 24 & 0 & 0 & 0 & 352 & 0 & 0 \\
\hline 25 & 0 & 0 & 0 & 586 & 0 & 0 \\
\hline 33 & 0 & 0 & 0 & 1,302 & 0 & 0 \\
\hline 34 & 0 & 0 & 0 & 698 & 0 & 0 \\
\hline 37 & 0 & 0 & 0 & 867 & 0 & 0 \\
\hline IMPLND AREA (acres) & 14 & 14.3 & 14.4 & 14.5 & .1 & .1 \\
\hline NRECH & 5 & 1 & 1 & 10 & 1 & 1 \\
\hline LEN (mi) & $1.88-4.35$ & 4.03 & .89 & $4.97-21.7$ & 7.95 & 1.31 \\
\hline \multicolumn{7}{|l|}{ FTABLE } \\
\hline DEPTH (ft) & $0-24.0$ & $0-19.8$ & 0-20.7 & $0-19.8$ & $0-6.48$ & $0-48.1$ \\
\hline SAREA (acres) & $0-259$ & $0-208$ & $0-106$ & $0-815$ & $0-101$ & $0-306$ \\
\hline VOL (acre-ft) & $0-3,270$ & $0-2,140$ & $0-125$ & $0-7,900$ & $0-308$ & $0-3,246$ \\
\hline DISCH $\left(\mathrm{ft}^{3} / \mathrm{s}\right)$ & $0-64,900$ & $0-32,000$ & $0-43,400$ & $0-41,400$ & $0-2,200$ & $0-4,000$ \\
\hline CHNLOSS $\left(\mathrm{ft}^{3} / \mathrm{s}\right)$ & 0 & $0-50$ & $0-26$ & $0-167$ & $0-37$ & $0-169$ \\
\hline
\end{tabular}

${ }^{1}$ The user's manual for Hydrological Simulation Program-FORTRAN (Bicknell and others, 1997) provides a more complete description of each parameter. 
stage-discharge relation defined at the streamflowgaging station; (2) water-surface-profile model simulations using WSPRO (Shearman, 1990); or (3) subbasins with similar geologic and slope characteristics.

\section{Model Calibration and Testing}

The HSPF model was calibrated using data from the Seco Creek at Miller Ranch and Parkers Creek Reservoir Inflow streamflow-gaging stations and spatially tested using data from the four remaining streamflow-gaging stations. Simulation periods for each subbasin are as follows: July 1, 1992-September 30, 1998, for Seco Creek at Miller Ranch; July 1, 1992September 30, 1998, for Seco Creek Reservoir Inflow; July 1, 1992-June 21, 1997, for Seco Creek Reservoir Outflow; July 1, 1992-June 19, 1997, for Seco Creek at Rowe Ranch; January 1, 1991-June 19, 1997, for Parkers Creek Reservoir Inflow; and January 1, 1991June 19, 1997, for Parkers Creek Reservoir Outflow. These time periods were selected on the basis of the results of initial simulations and available data. Initial conditions during January 1, 1991-June 30, 1992, were very wet. At Seco Creek at Miller Ranch, initial model simulations that included the 1991 time period consistently oversimulated runoff in the subsequent years. Because it was not possible to determine a reasonable set of initial conditions prior to July 1992, the start of the simulation period was changed.

Initial estimates for the 20 process-related parameters were (1) based on the physical properties of geology, land cover, soils, and slopes in the subbasins (Chow and others, 1988); or (2) assigned the default values listed in table 2 . The 16 calibration annual parameter values are listed in table 5, the one calibration monthly parameter value is listed in table 6 , and the three initial-condition values are listed in table 7.

Parameter values varied by geology and land cover corresponding to the physical process that the parameter represents. For example, the parameter values for AGWETP, AGWRC, BASETP, DEEPFR, INFILT, INTFW, IRC, KVARY, and LZSN varied by geology and represented the different storage and infiltration capacities of the soil and bedrock, whereas the parameter value for UZSN varied by land cover and represented the different surface roughness, interception storages, and ET potentials of the land-cover groups (table 5). The parameter values for SLSUR varied by individual subbasin slopes. The parameter values for CEPSC were assumed to be uniform for all land seg- ments. The parameter values for INTFW, IRC, and NSUR were not varied monthly because data were not available to support use of seasonal variations. Monthly values for LZETP were used to account for seasonal differences in ET potential (table 6). ET potential is greatest during late spring and summer, and it is least during winter.

Values of the annual parameters (AGWETP, AGWRC, BASETP, CEPSC, DEEPFR, INFEXP, INFILD, INFILT, INTFW, IRC, KVARY, LSUR, LZSN, NSUR, SLSUR, and UZSN) and values of the monthly parameter (LZETP) were adjusted during the calibration process using the software program HSPEXP (Lumb and others, 1994). The values for the initial-condition parameters (AGWS, LZS, and UZS) were initially estimated from default values and were revised during calibration. These values were varied by land segment; the values for all subbasins are presented in table 7 . The predominant land cover in each subbasin had the greatest impact on selecting initial-condition values. An iterative process was used to determine initial-condition values, which produced the best (best match of simulated and beginning observed runoff) model simulation results.

The iteratively calibrated parameter set (tables 56) was developed from 33 storms-17 in the Seco Creek at Miller Ranch subbasin and 16 in the Parkers Creek Reservoir Inflow subbasin. Another 27 storms were used to test the parameters spatially to assess the transferability of the parameter set to the other four subbasins. Parameter testing was done in the following subbasins: Seco Creek Reservoir Inflow (13 storms), Seco Creek Reservoir Outflow (4 storms), Seco Creek at Rowe Ranch (4 storms), and Parkers Creek Reservoir Outflow (6 storms).

Simulated and measured (observed) monthly flows are presented in figures 5-10 for the six Seco Creek subbasins. Simulated flow for the six subbasins generally compares favorably with observed flow. Flow occurs more than 95 percent of the time in the Seco Creek at Miller Ranch subbasin, about 11 percent of the time in the Seco Creek Reservoir Inflow subbasin, about 1 percent of the time in the Parkers Creek Reservoir Inflow subbasin, and less than 1 percent of the time in the Seco Creek Reservoir Outflow, Seco Creek at Rowe Ranch, and Parkers Creek Reservoir Outflow subbasins. Model simulations indicate surface runoff (overland flow) is the major component of the flow for the Seco Creek Reservoir Outflow (fig. 7) and Seco Creek at Rowe Ranch (fig. 8) subbasins; whereas, base 

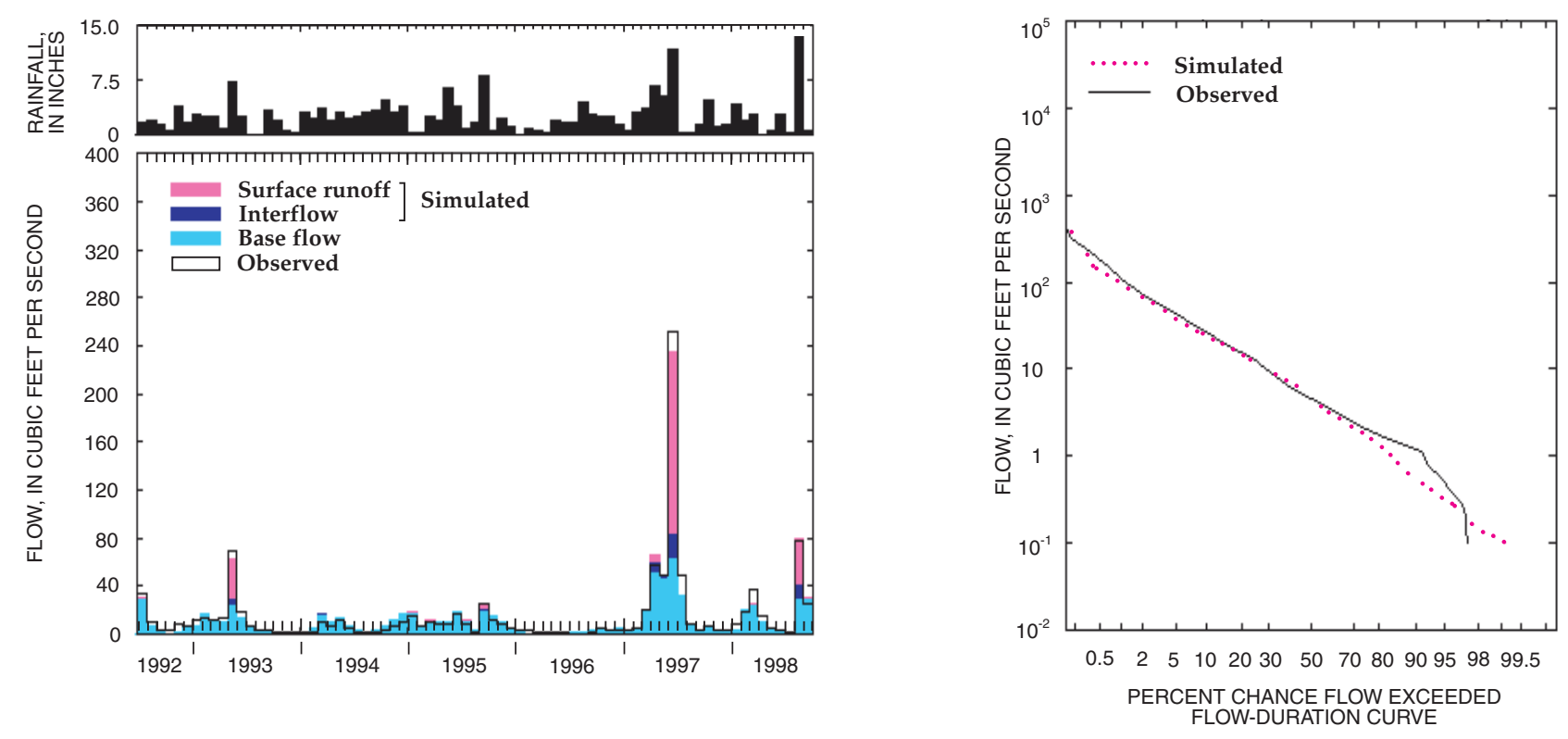

Figure 5. Simulated and observed flow for 08201500 Seco Creek at Miller Ranch near Utopia.
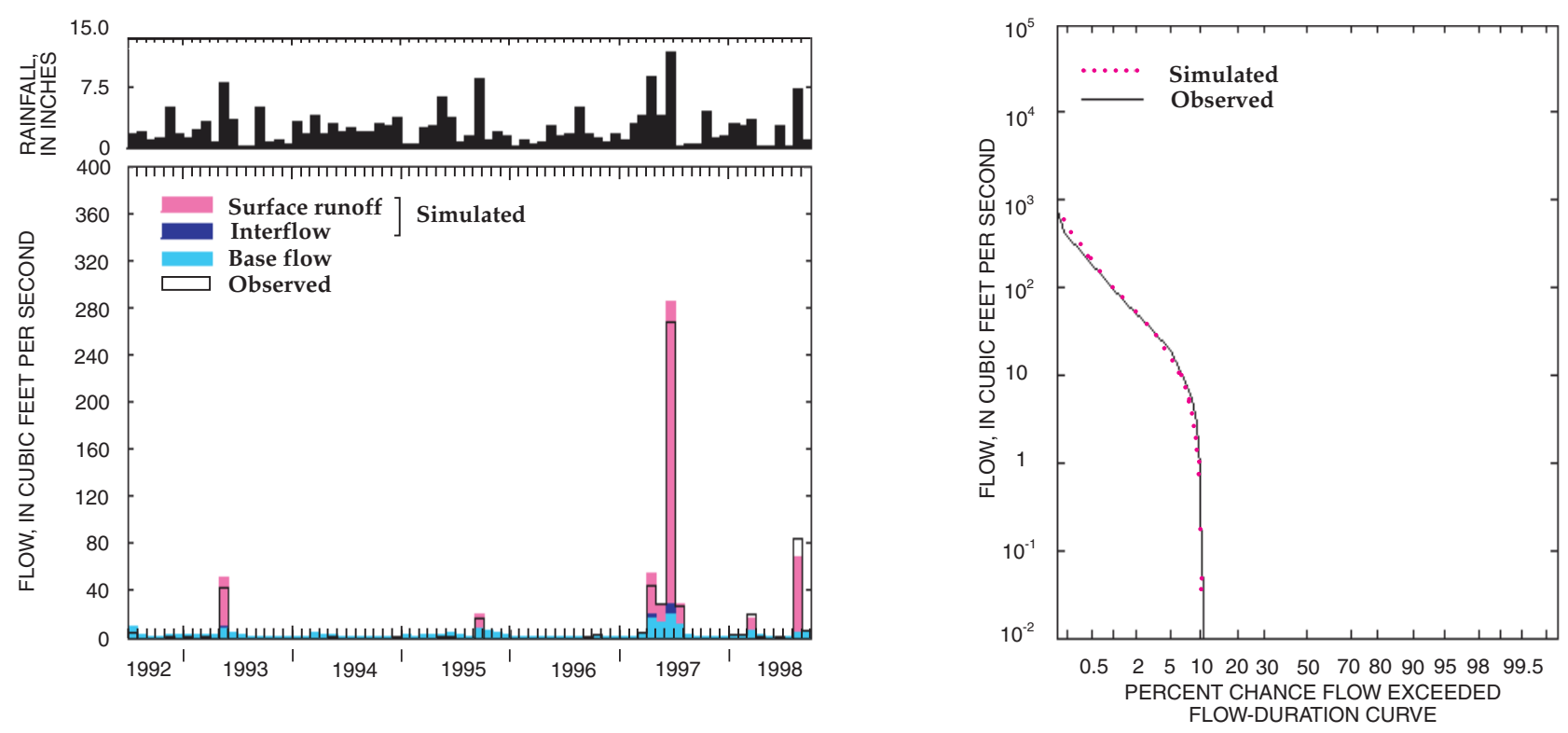

Figure 6. Simulated and observed flow for 08202450 Seco Creek Reservoir Inflow near Utopia.

flow is the major component of the flow for the Parkers Creek Reservoir Outflow (fig. 10) subbasin. Model simulations indicate that surface runoff and base flow both contribute to flow for the Seco Creek at Miller Ranch (fig. 5), Seco Creek Reservoir Inflow (fig. 6), and Parkers Creek Reservoir Inflow (fig. 9) subbasins.

A summary of calibration and testing results by subbasin are presented in table 8. Results comprise ET, annual runoff, highest 10 percent of flows, lowest 50 percent of flows, storm volumes, simulated storm interflow, simulated storm surface runoff, summer flow volume, winter flow volume, and summer storm volume. Table 9 presents calibration and testing errors for the entire simulation period by subbasin.

Simulated ET ranged from 119 in. for the Seco Creek at Rowe Ranch subbasin to 164 in. for the Seco 

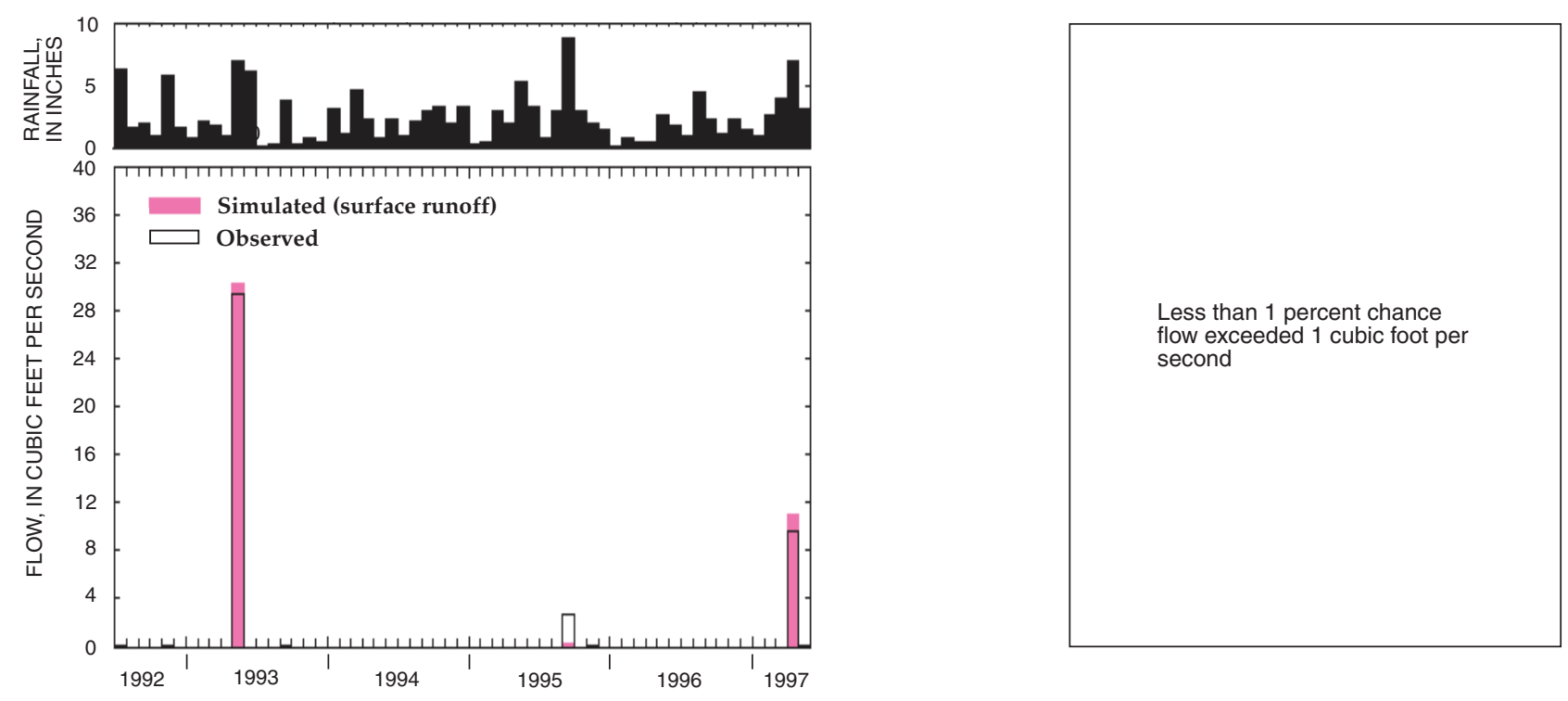

Figure 7. Simulated and observed flow for 08202490 Seco Creek Reservoir Outflow near Utopia.
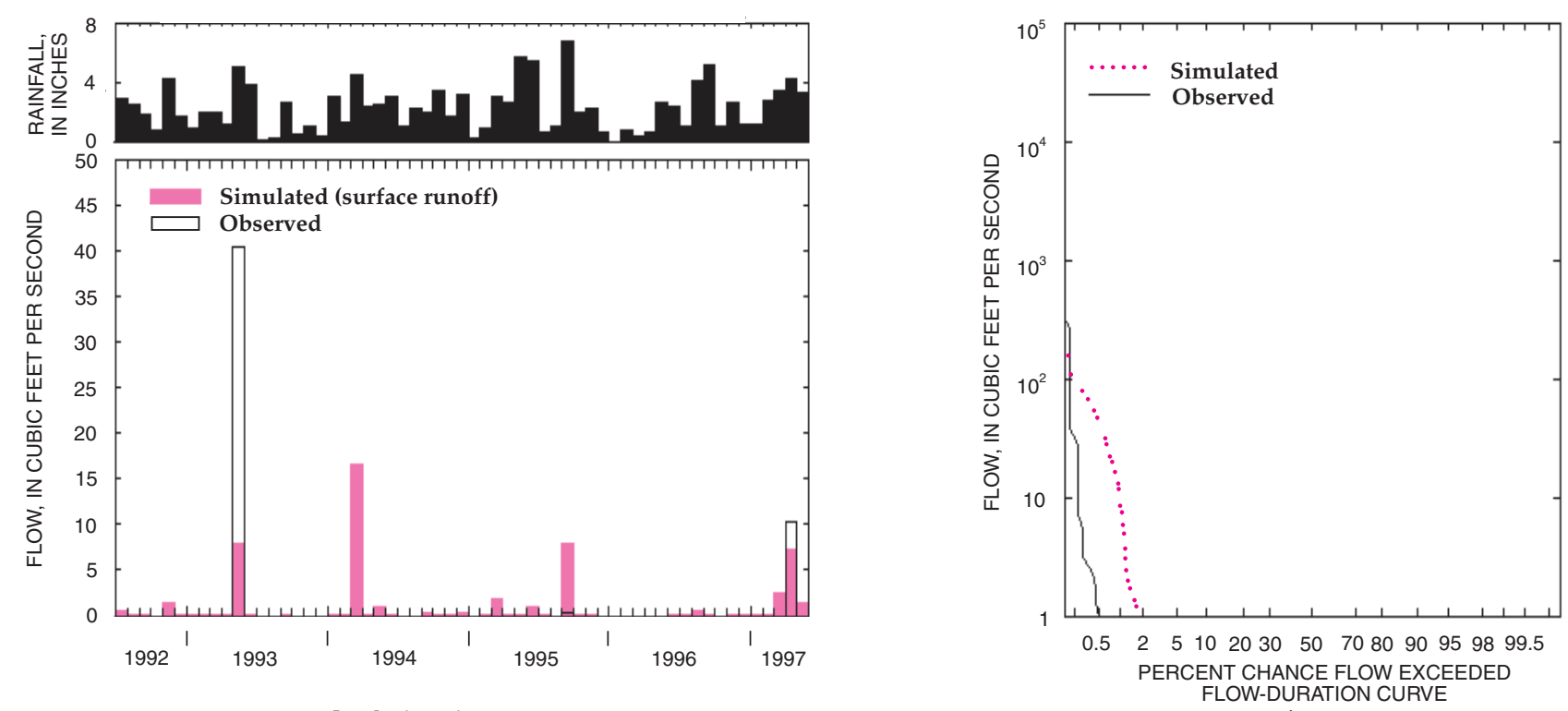

Figure 8. Simulated and observed flow for 08202700 Seco Creek at Rowe Ranch near D'Hanis.

Creek at Miller Ranch subbasin. Intuitively, this appears reasonable because the least amount of rainfall occurs in the Seco Creek at Rowe Ranch subbasin (less water is available for ET), and the greatest amount of rainfall occurs in the Seco Creek at Miller Ranch subbasin (more water is available for ET).

The simulated annual runoff volumes for all subbasins match well with observed annual runoff volumes for the calibration and testing periods. Maximum simulated annual runoff volumes occurred at Seco Creek at Miller Ranch and Seco Creek Reservoir Inflow (above Edwards aquifer recharge zone), and minimum annual runoff volumes occurred at Seco Creek at Rowe Ranch and Parkers Creek Reservoir Outflow (on and below the Edwards aquifer recharge zone). More annual runoff occurs in subbasins that are predominantly Glen Rose 

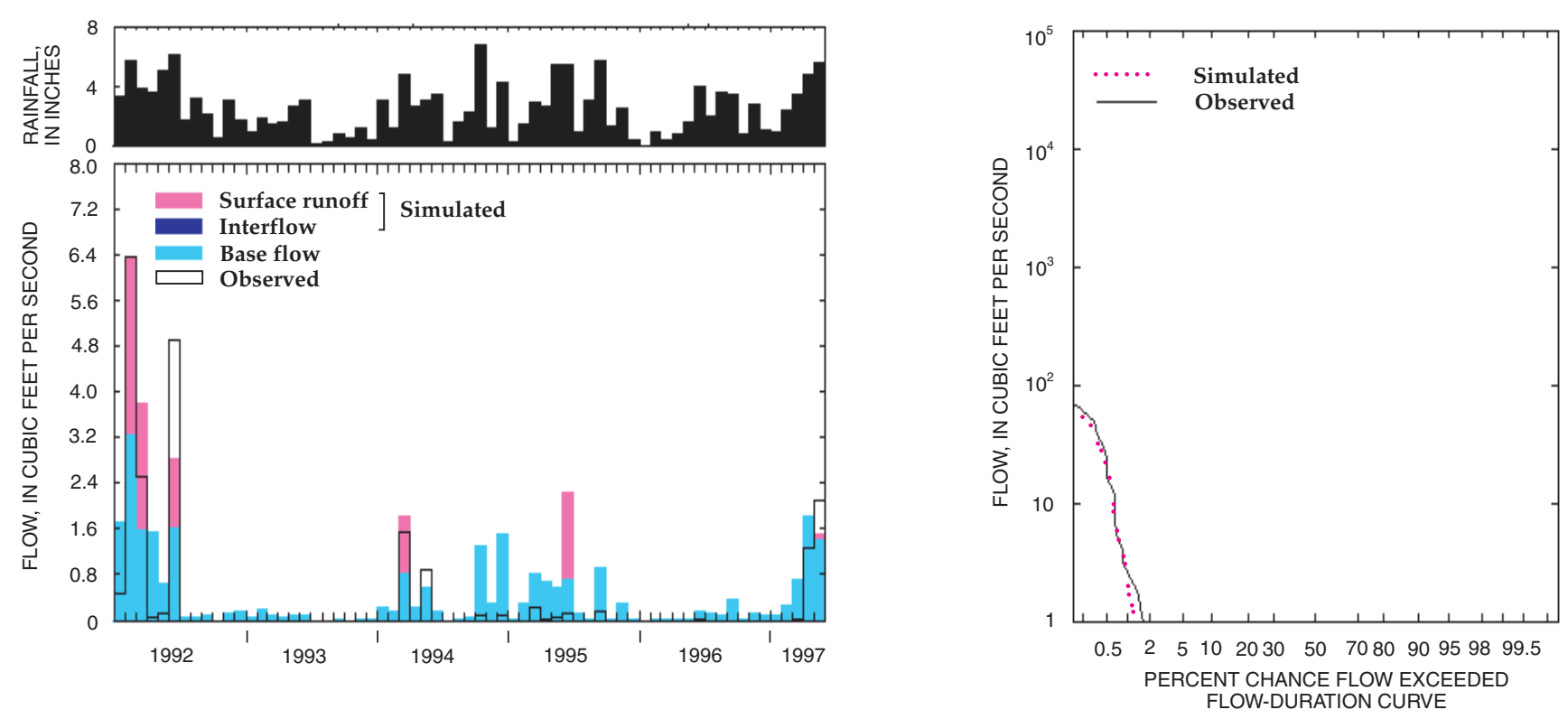

Figure 9. Simulated and observed flow for 08202790 Parkers Creek Reservoir Inflow near D'Hanis.
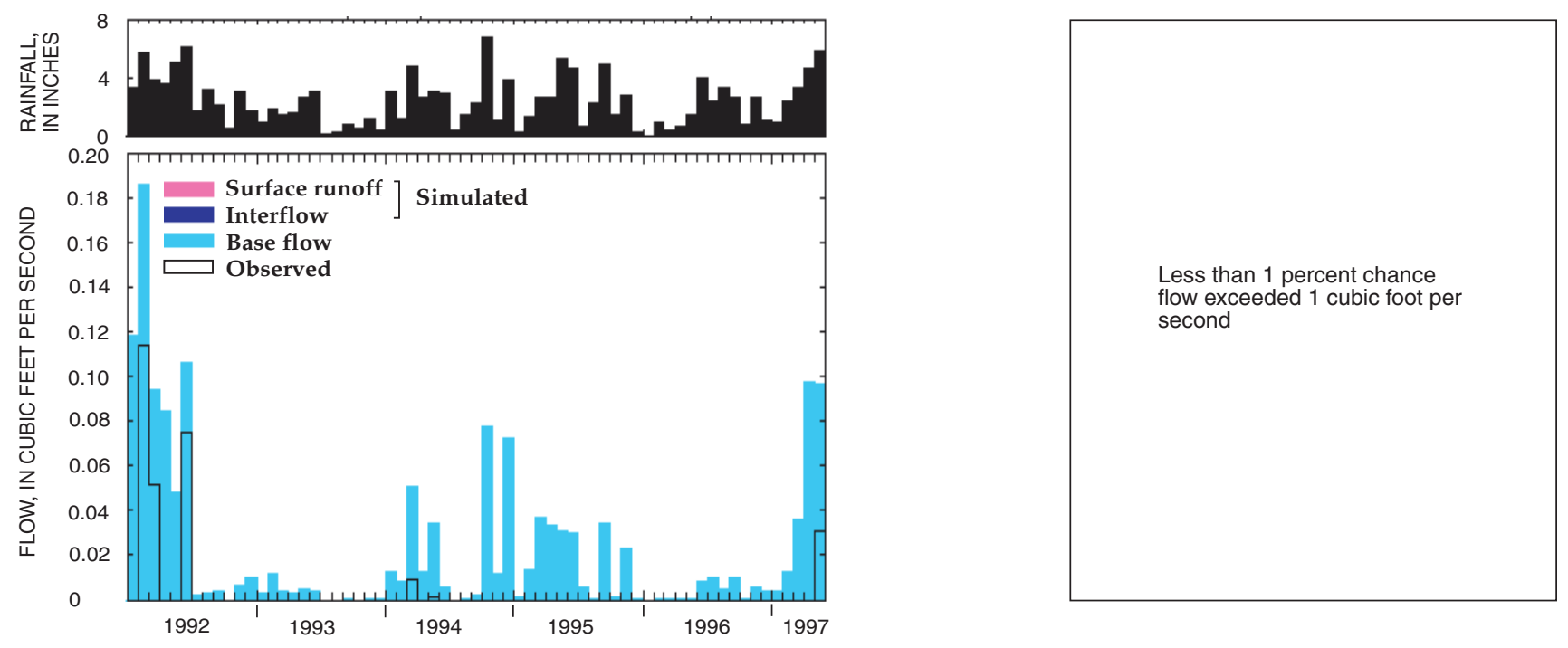

Figure 10. Simulated and observed flow for 08202810 Parkers Creek Reservoir Outflow near D'Hanis.

Limestone than subbasins that are predominantly Devils River Formation, which is reasonable because the Glen Rose generally is less permeable than the Devils River.

Simulated highest 10 percent of flows for all subbasins match well with observed data. Analysis of the lowest 50 percent of flows indicates that Seco Creek at Miller Ranch is the only subbasin with consistent base flow. In the other five subbasins all of the flow occurs during 10 percent of the year. In other words, at least 90 percent of the time there is no flow at Seco Creek Reservoir Inflow, Seco Creek Reservoir Outflow, Seco Creek at Rowe Ranch, Parkers Creek Reservoir Inflow, and Parkers Creek Reservoir Outflow. Channel losses to the Glen Rose Limestone and Devils River Formation and high infiltration rates capture low flows in these five subbasins. 


\section{Table 5. Calibration annual parameters}

[Land segments characterized and designated by 2-digit geology/land-cover descriptor: 01, Devils River Formation rangeland; 02, Buda Limestone rangeland; 03, Devils River Formation pasture/hay; 04, Eagle Ford Group pasture/hay; 05, Eagle Ford Group rangeland; 06, Austin Group rangeland; 07, Del Rio Clay rangeland; 08, Glen Rose Limestone rangeland; 09, Glen Rose Limestone pasture/hay; 10, alluvium pasture/hay; 11, alluvium rangeland; 12, Fort Terrett Formation rangeland; 13, Segovia Formation rangeland; 17, Leona Formation cropland; 18, Leona Formation rangeland; 20, Leona Formation irrigated cropland; 24 Leona Formation irrigated pasture/hay; 25, Leona Formation pasture/hay; 33, Anacacho Limestone rangeland; 34, Austin Group cropland; 37, Uvalde Gravel rangeland

Parameter definitions in table 2; units below parameter except where no units. /d, per day; in., inches; in/hr, inches per hour; /in., per inch; $\mathrm{ft}$, feet; ft/ft, foot per foot]

\begin{tabular}{|c|c|c|c|c|c|c|c|c|}
\hline $\begin{array}{c}\text { Land } \\
\text { segment }\end{array}$ & AGWETP ${ }^{1,3}$ & $\begin{array}{c}\text { AGWRC }^{2,3} \\
\text { (/d) }\end{array}$ & BASETP ${ }^{3}$ & $\begin{array}{c}\text { CEPSC }^{3} \\
\text { (in.) }\end{array}$ & DEEPFR ${ }^{3}$ & INFEXP $^{1}$ & INFILD $^{1}$ & $\begin{array}{c}\text { INFILT }^{3} \\
\text { (in/hr) }\end{array}$ \\
\hline 01 & 0 & 0.01 & 0.01 & 0.04 & 0.96 & 2.0 & 2.0 & 0.32 \\
\hline 02 & 0 & .01 & .01 & .04 & .06 & 2.0 & 2.0 & .08 \\
\hline 03 & 0 & .01 & .01 & .04 & .96 & 2.0 & 2.0 & .32 \\
\hline 04 & 0 & .01 & .01 & .04 & .06 & 2.0 & 2.0 & .08 \\
\hline 05 & 0 & .01 & .01 & .04 & .06 & 2.0 & 2.0 & .08 \\
\hline 06 & 0 & .01 & .01 & .04 & .06 & 2.0 & 2.0 & .08 \\
\hline 07 & 0 & .10 & .01 & .04 & .02 & 2.0 & 2.0 & .08 \\
\hline 08 & 0 & .96 & 0 & .04 & .02 & 2.0 & 2.0 & .32 \\
\hline 09 & 0 & .96 & 0 & .04 & .02 & 2.0 & 2.0 & .32 \\
\hline 10 & 0 & .85 & .05 & .04 & .02 & 2.0 & 2.0 & .82 \\
\hline 11 & 0 & .85 & .05 & .04 & .02 & 2.0 & 2.0 & .82 \\
\hline 12 & 0 & .50 & 0 & .04 & .50 & 2.0 & 2.0 & .62 \\
\hline 13 & 0 & .50 & 0 & .04 & .50 & 2.0 & 2.0 & .62 \\
\hline 17 & .20 & .01 & .20 & .04 & .99 & 2.0 & 2.0 & 1.00 \\
\hline 18 & .20 & .01 & .20 & .04 & .99 & 2.0 & 2.0 & 1.00 \\
\hline 20 & .20 & .01 & .20 & .04 & .99 & 2.0 & 2.0 & 1.00 \\
\hline 24 & .20 & .01 & .20 & .04 & .99 & 2.0 & 2.0 & 1.00 \\
\hline 25 & .20 & .01 & .20 & .04 & .99 & 2.0 & 2.0 & 1.00 \\
\hline 33 & 0 & .01 & .05 & .04 & .04 & 2.0 & 2.0 & .15 \\
\hline 34 & 0 & .01 & .05 & .04 & .06 & 2.0 & 2.0 & .11 \\
\hline 37 & 0 & .01 & .05 & .04 & .02 & 2.0 & 2.0 & .75 \\
\hline $\begin{array}{c}\text { Land } \\
\text { segment }\end{array}$ & INTFW $^{3}$ & $\begin{array}{c}\text { IRC }^{2,3} \\
\text { (/d) }\end{array}$ & $\begin{array}{c}\text { KVARY }^{1,3} \\
\text { (/in.) }\end{array}$ & $\begin{array}{c}\text { LSUR }^{3} \\
\text { (ft) }\end{array}$ & $\begin{array}{c}\text { LZSN }^{3} \\
\text { (in.) }\end{array}$ & NSUR $^{3,4}$ & $\begin{array}{c}\text { SLSUR }^{3} \\
(\mathrm{ft} / \mathrm{ft})\end{array}$ & $\begin{array}{c}\text { UZSN }^{3} \\
\text { (in.) }\end{array}$ \\
\hline 01 & 0.001 & 0.01 & 0 & 800 & 4.00 & 0.15 & 0.090 & 0.22 \\
\hline 02 & .100 & .10 & 0 & 800 & 4.00 & .15 & .090 & .22 \\
\hline 03 & .001 & .01 & 0 & 800 & 4.00 & .15 & .090 & .22 \\
\hline 04 & .100 & .10 & 0 & 800 & 4.00 & .15 & .090 & .22 \\
\hline 05 & .100 & .10 & 0 & 800 & 4.00 & .15 & .090 & .22 \\
\hline 06 & .100 & .10 & 0 & 800 & 4.00 & .15 & .090 & .22 \\
\hline 07 & .001 & .10 & 0 & 800 & 4.00 & .15 & .090 & .22 \\
\hline 08 & .80 & .60 & .04 & 800 & 5.50 & .15 & .080 & .40 \\
\hline 09 & .80 & .60 & .04 & 800 & 5.50 & .15 & .080 & .40 \\
\hline 10 & .10 & .30 & 0 & 800 & 5.50 & .15 & .015 & .35 \\
\hline 11 & .10 & .30 & 0 & 800 & 5.50 & .15 & .015 & .35 \\
\hline 12 & .10 & .10 & 0 & 800 & 5.50 & .15 & .097 & .35 \\
\hline 13 & .10 & .10 & 0 & 800 & 5.50 & .15 & .119 & .30 \\
\hline 17 & .01 & .01 & 0 & 800 & 9.00 & .15 & .016 & .55 \\
\hline 18 & .01 & .01 & 0 & 800 & 9.00 & .15 & .016 & .55 \\
\hline 20 & .01 & .01 & 0 & 800 & 9.00 & .15 & .016 & .55 \\
\hline 24 & .01 & .01 & 0 & 800 & 9.00 & .15 & .016 & .55 \\
\hline 25 & .01 & .01 & 0 & 800 & 9.00 & .15 & .010 & .55 \\
\hline 33 & .01 & .01 & 0 & 800 & 4.00 & .15 & .010 & .22 \\
\hline 34 & .01 & .01 & 0 & 800 & 4.00 & .15 & .010 & .22 \\
\hline 37 & .01 & .01 & 0 & 800 & 5.00 & .15 & .010 & .35 \\
\hline
\end{tabular}




\section{Table 6. Calibration monthly parameter}

[Land segments characterized and designated by 2-digit geology/land-cover descriptor: 01, Devils River Formation rangeland; 02, Buda Limestone rangeland; 03, Devils River Formation pasture/hay; 04, Eagle Ford Group pasture/hay; 05, Eagle Ford Group rangeland; 06, Austin Group rangeland; 07, Del Rio Clay rangeland; 08, Glen Rose Limestone rangeland; 09, Glen Rose Limestone pasture/hay; 10, alluvium pasture/hay; 11, alluvium rangeland; 12, Fort Terrett Formation rangeland; 13, Segovia Formation rangeland; 17, Leona Formation cropland; 18, Leona Formation rangeland; 20, Leona Formation irrigated cropland; 24 Leona Formation irrigated pasture/hay; 25, Leona Formation pasture/hay; 33, Anacacho Limestone rangeland; 34, Austin Group cropland; 37, Uvalde Gravel rangeland

Parameter definition in table 2; LZETP has no units]

\begin{tabular}{|c|c|c|c|c|c|c|c|c|c|c|c|c|}
\hline $\begin{array}{c}\text { Land } \\
\text { segment }\end{array}$ & Jan. & Feb. & Mar. & Apr. & May & June & July & Aug. & Sept. & Oct. & Nov. & Dec. \\
\hline \multicolumn{13}{|c|}{ LZETP $^{1,2}$} \\
\hline 01-13 & 0.27 & 0.27 & 0.32 & 0.37 & 0.42 & 0.45 & 0.58 & 0.58 & 0.60 & 0.47 & 0.35 & 0.35 \\
\hline $17-18$ & .27 & .27 & .32 & .37 & .42 & .45 & .58 & .58 & .60 & .47 & .35 & .35 \\
\hline 20 & .27 & .27 & .32 & .37 & .42 & .45 & .58 & .58 & .60 & .47 & .35 & .35 \\
\hline $24-25$ & .27 & .27 & .32 & .37 & .42 & .45 & .58 & .58 & .60 & .47 & .35 & .35 \\
\hline $33-34$ & .27 & .27 & .32 & .37 & .42 & .45 & .58 & .58 & .60 & .47 & .35 & .35 \\
\hline 37 & .27 & .27 & .32 & .37 & .42 & .45 & .58 & .58 & .60 & .47 & .35 & .35 \\
\hline
\end{tabular}

${ }^{1}$ Initial estimate was default value.

${ }^{2}$ Parameter revised during calibration.

Table 7. Initial-condition values for model calibration

[Land segments characterized and designated by 2-digit geology/land-cover descriptor: 01, Devils River Formation rangeland; 02, Buda Limestone rangeland; 03, Devils River Formation pasture/hay; 04, Eagle Ford Group pasture/hay; 05, Eagle Ford Group rangeland; 06, Austin Group rangeland; 07, Del Rio Clay rangeland; 08, Glen Rose Limestone rangeland; 09, Glen Rose Limestone pasture/hay; 10, alluvium pasture/hay; 11, alluvium rangeland; 12, Fort Terrett Formation rangeland; 13, Segovia Formation rangeland; 17, Leona Formation cropland; 18, Leona Formation rangeland; 20, Leona Formation irrigated cropland; 24 Leona Formation irrigated pasture/hay; 25, Leona Formation pasture/hay; 33, Anacacho Limestone rangeland; 34, Austin Group cropland; 37, Uvalde Gravel rangeland

Parameter definitions in table 2; units below parameter. in., inches]

\begin{tabular}{lcccc}
\hline \multicolumn{1}{c}{ Station } & $\begin{array}{c}\text { Land } \\
\text { segments }\end{array}$ & $\begin{array}{c}\text { AGWS } \\
\text { (in.) }\end{array}$ & $\begin{array}{c}\text { LZS }^{1,2} \\
\text { (in.) }\end{array}$ & $\begin{array}{c}\text { UZS }^{1,2} \\
\text { (in.) }\end{array}$ \\
\hline Miller Ranch & $08-13$ & 0.9 & 4.0 & 0 \\
Seco Creek Reservoir Inflow & $08-12$ & .9 & 4.0 & 0 \\
Seco Creek Reservoir Outflow & 01 & 0 & 4.4 & 0 \\
& $08-11$ & .9 & 4.0 & 0 \\
Rowe Ranch & $01-07$ & 0 & 4.4 & 0 \\
& $08-13$ & .9 & 2.0 & .2 \\
& $17-18$ & 0 & 2.0 & .2 \\
Parkers Creek Reservoir Inflow & 20 & 0 & 2.0 & .2 \\
Parkers Creek Reservoir Outflow & $24-25$ & 0 & 2.0 & .2 \\
\hline
\end{tabular}


Table 8. Summary of calibration and testing results for upper Seco Creek subbasins

[Volumes, in inches, are cumulative for entire simulation period for each subbasin and are computed on the basis of individual subbasin drainage areas. Sim., simulated; Obs., observed; in., inches; --, not measured]

\begin{tabular}{|c|c|c|c|c|c|c|}
\hline & \multicolumn{2}{|c|}{$\begin{array}{l}\text { Miller } \\
\text { Ranch }\end{array}$} & \multicolumn{2}{|c|}{$\begin{array}{l}\text { Seco Creek } \\
\text { Reservoir } \\
\text { Inflow }\end{array}$} & \multicolumn{2}{|c|}{$\begin{array}{c}\text { Seco Creek } \\
\text { Reservoir } \\
\text { Outflow }\end{array}$} \\
\hline & $\begin{array}{l}\text { Sim. } \\
\text { (in.) }\end{array}$ & $\begin{array}{l}\text { Obs. } \\
\text { (in.) }\end{array}$ & $\begin{array}{l}\text { Sim. } \\
\text { (in.) }\end{array}$ & $\begin{array}{l}\text { Obs. } \\
\text { (in.) }\end{array}$ & $\begin{array}{l}\text { Sim. } \\
\text { (in.) }\end{array}$ & $\begin{array}{l}\text { Obs. } \\
\text { (in.) }\end{array}$ \\
\hline Evapotranspiration & 164 & -- & 157 & -- & 127 & -- \\
\hline Annual runoff & 26.1 & 27.3 & 45.2 & 44.5 & 23.9 & 24.0 \\
\hline Highest 10 percent of flows & 16.0 & 16.9 & 45.2 & 44.5 & 23.9 & 24.0 \\
\hline Lowest 50 percent of flows & 1.75 & 2.02 & 0 & 0 & 0 & 0 \\
\hline Volume of selected storms & 6.05 & 5.79 & 14.8 & 15.7 & 23.9 & 23.9 \\
\hline Interflow & 1.16 & -- & 1.31 & -- & .18 & -- \\
\hline Surface runoff & 5.96 & -- & 5.37 & -- & 1.17 & -- \\
\hline Summer flow volume & 11.6 & 12.5 & 30.4 & 30.4 & .03 & .01 \\
\hline Winter flow volume & 3.03 & 3.06 & .40 & .59 & 0 & 0 \\
\hline \multirow[t]{3}{*}{ Summer storm volume } & 2.03 & 1.95 & 5.80 & 7.17 & 0 & 0 \\
\hline & \multicolumn{2}{|c|}{$\begin{array}{l}\text { Rowe } \\
\text { Ranch }\end{array}$} & \multicolumn{2}{|c|}{$\begin{array}{l}\text { Parkers Creek } \\
\text { Reservoir } \\
\text { Inflow }\end{array}$} & \multicolumn{2}{|c|}{$\begin{array}{c}\text { Parkers Creek } \\
\text { Reservoir } \\
\text { Outflow }\end{array}$} \\
\hline & $\begin{array}{l}\text { Sim. } \\
\text { (in.) }\end{array}$ & $\begin{array}{l}\text { Obs. } \\
\text { (in.) }\end{array}$ & $\begin{array}{l}\text { Sim. } \\
\text { (in.) }\end{array}$ & $\begin{array}{l}\text { Obs. } \\
\text { (in.) }\end{array}$ & $\begin{array}{l}\text { Sim. } \\
\text { (in.) }\end{array}$ & $\begin{array}{l}\text { Obs. } \\
\text { (in.) }\end{array}$ \\
\hline Evapotranspiration & 119 & -- & 136 & -- & 131 & -- \\
\hline Annual runoff & .57 & 0.58 & 2.48 & 2.57 & .44 & 0.44 \\
\hline Highest 10 percent of flows & .56 & .57 & 2.48 & 2.56 & .44 & .44 \\
\hline Lowest 50 percent of flows & 0 & 0 & 0 & 0 & 0 & 0 \\
\hline Volume of selected storms & .09 & .12 & 1.88 & 2.01 & .38 & .35 \\
\hline Interflow & .07 & -- & 0 & -- & 0 & -- \\
\hline Surface runoff & .57 & -- & 3.11 & -- & 1.75 & -- \\
\hline Summer flow volume & .03 & .01 & .61 & .66 & .08 & .12 \\
\hline Winter flow volume & 0 & 0 & .82 & .80 & .23 & .17 \\
\hline Summer storm volume & 0 & .01 & .09 & .13 & .08 & .12 \\
\hline
\end{tabular}

Table 9. Summary of calibration and testing errors for upper Seco Creek subbasins

\begin{tabular}{lcccccc}
\hline & $\begin{array}{c}\text { Miller } \\
\text { Ranch } \\
\text { error } \\
\text { (percent) }\end{array}$ & $\begin{array}{c}\text { Seco Creek } \\
\text { Reservoir } \\
\text { Inflow error } \\
\text { (percent) }\end{array}$ & $\begin{array}{c}\text { Seco Creek } \\
\text { Reservoir } \\
\text { Outflow error } \\
\text { (percent) }\end{array}$ & $\begin{array}{c}\text { Rowe } \\
\text { Ranch error } \\
\text { (percent) }\end{array}$ & $\begin{array}{c}\text { Parkers Creek } \\
\text { Reservoir } \\
\text { Inflow error } \\
\text { (percent) }\end{array}$ & $\begin{array}{c}\text { Parkers Creek } \\
\text { Reservoir } \\
\text { Outflow error } \\
\text { (percent) }\end{array}$ \\
\hline Annual runoff & -4.2 & 1.5 & -0.2 & -1.4 & -3.4 & -3.4 \\
Highest 10 percent of flows & -5.2 & 1.5 & -.2 & -1.8 & 0 & 0 \\
Lowest 50 percent of flows & -13.4 & 0 & 0 & 0 & 0 \\
\hline
\end{tabular}


The simulated storm volumes matched fairly well (within 10 percent) with observed data for all subbasins except Seco Creek at Rowe Ranch. However, the observed storm volume at Seco Creek at Rowe Ranch was small in comparison to the other five subbasins.

Simulated storm interflow was greatest (1.31 in.) for the Seco Creek Reservoir Inflow subbasin and zero for the Parkers Creek Reservoir Inflow and Outflow subbasins. Total simulated storm surface runoff was greatest (more than 5.0 in.) for the Seco Creek at Miller Ranch and Seco Creek Reservoir Inflow subbasins (both located primarily on the Glen Rose Limestone) and substantially less ( 0.57 in.) for the Seco Creek at Rowe Ranch subbasin (located on and below the Edwards aquifer recharge zone).

Results of simulated and observed summer and winter flow volumes for subbasins varied. Simulated summer flow volumes matched fairly well with observed data for all subbasins, and simulated winter flow volumes matched fairly well with observed data for all subbasins. Seco Creek Reservoir Inflow and Parkers Creek Reservoir Outflow had the greatest errors associated with simulated winter flow volumes.

The summer storm volumes were the most difficult to simulate. Summer storms typically are of short duration, intense, and limited in geographical extent, which makes modeling of individual summer storms difficult. Seco Creek at Miller Ranch, Seco Creek Reservoir Outflow, Seco Creek at Rowe Ranch, Parkers Creek Reservoir Inflow, and Parkers Creek Reservoir Outflow simulations matched well with observed data. Simulations for the Seco Creek Reservoir Inflow subbasin substantially undersimulated summer storm volumes.

\section{Error Analysis}

The types of errors from the model calibration and testing can be classified as measurement errors or systematic errors. Measurement errors are introduced as a result of missing data, inaccurate stage-discharge relations, and unknown channel losses. Data were missing for several rainfall stations and had to be estimated from adjacent rain gages, particularly in the Seco Creek at Rowe Ranch subbasin. The streamflow-gaging stations at Seco Creek Reservoir Inflow and Seco Creek at Rowe Ranch had the least accurate stage-discharge relations (for depths greater than wading), which likely resulted in inaccurate discharge records. Peak flows at Seco Creek Reservoir Inflow approached $17,000 \mathrm{ft}^{3} / \mathrm{s}$ (on the basis of an indirect measurement of discharge), whereas the maximum wading discharges were 600 to $900 \mathrm{ft}^{3} / \mathrm{s}$. Hence, the upper end (greater than $900 \mathrm{ft}^{3} / \mathrm{s}$ ) of the Seco Creek Reservoir Inflow rating is less accurate. Likewise, flows at Seco Creek at Rowe Ranch typically were measured only at wading stages. Channel losses to the Devils River Formation were estimated on the basis of channel losses measured in the reach between Seco Creek Reservoir Inflow and Seco Creek Reservoir Outflow and also in the reach between Parkers Creek Reservoir Inflow and Parkers Creek Reservoir Outflow. ET is a major component of the water budget. Errors between actual ET and simulated ET on the basis of measured pan evaporation are unknown.

Systematic errors are associated with the inability of the simulation model to represent the physical processes of runoff. These errors are represented in the model equations and selected model parameters. The PERLNDs used in this model might not have represented adequately all the different hydrologic response units of the study area. Also, some uncertainty existed in the values of each reach volume and the corresponding discharge for the FTABLES, particularly for the Seco Creek at Rowe Ranch subbasin.

Seasonal systematic errors might be detected by looking at differences between simulated and observed monthly discharge (fig. 11). Ideally, simulations for a given month would exhibit no errors or only those errors that are evenly distributed above and below zero. ET potential was adjusted to account for seasonal variation in runoff. ET rates change with seasons; these changes were simulated by adjusting the parameter values for LZETP (table 6). Differences in simulated monthly discharge were reasonably well distributed above and below zero for all subbasins with no apparent bias. The greatest and least differences between simulated and observed monthly discharges occurred in the Seco Creek at Rowe Ranch and Parkers Creek Reservoir Outflow subbasins, respectively.

\section{Sensitivity Analysis}

Sensitivity analyses were iteratively done during the calibration and testing process. The values of nearly all parameters in tables 5-7 were changed, and the results were evaluated. Each parameter was modified to represent a reasonable change and even an unreasonable change. In order of importance, the parameters INFILT, LZSN, LZETP, DEEPFR, UZSN, AGWRC, 

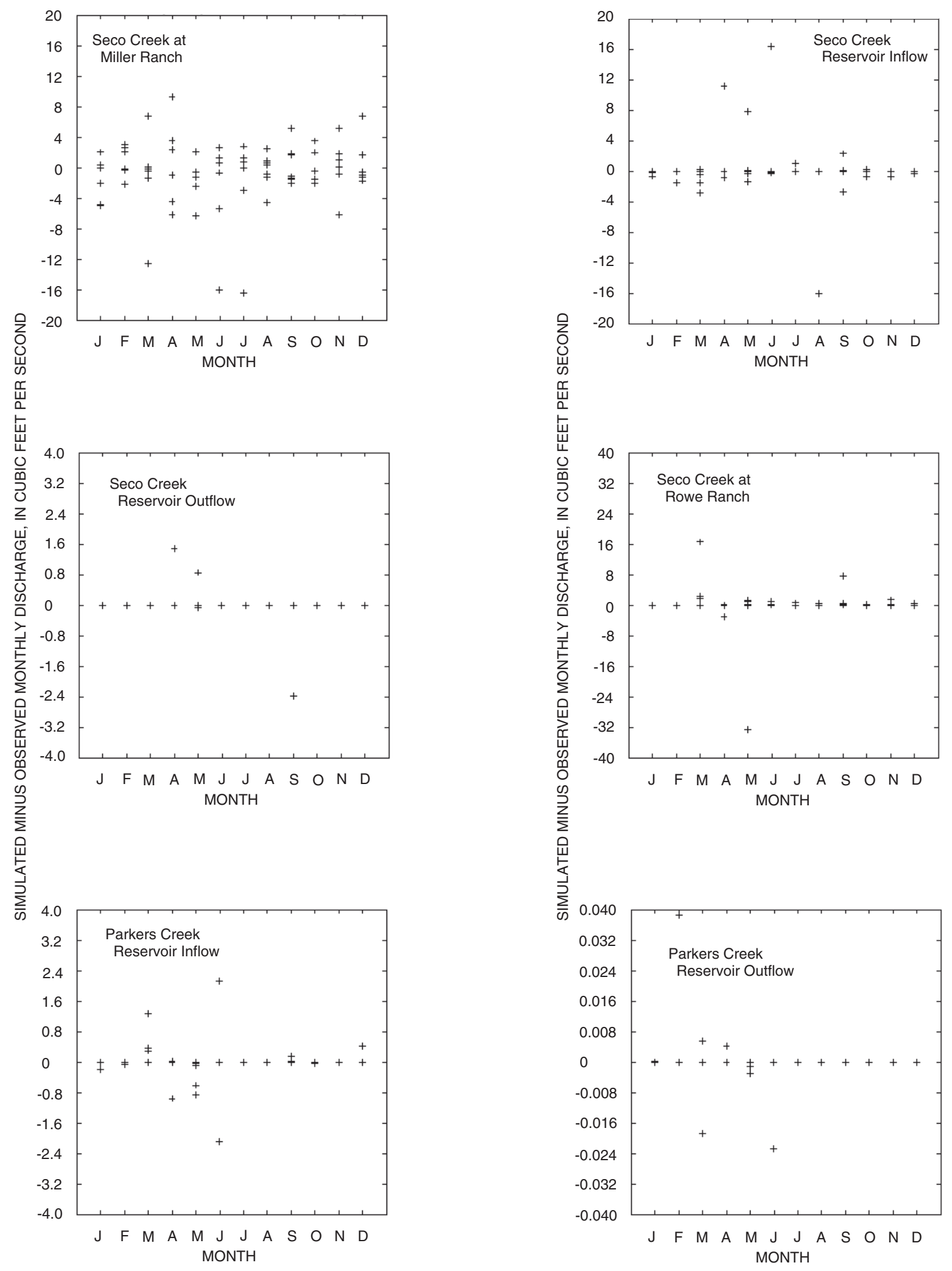

Figure 11. Difference between simulated and observed monthly discharge for upper Seco Creek subbasins. 
Table 10. Simulation results from a 5- to 6-percent reduction in evapotranspiration associated with brush management

[Reduction in evapotranspiration produced in the model by 20-percent reduction in value of LZET]

\begin{tabular}{|c|c|c|c|c|c|c|}
\hline & $\begin{array}{c}\text { Miller } \\
\text { Ranch } \\
\text { (percent } \\
\text { change) }\end{array}$ & $\begin{array}{l}\text { Seco Creek } \\
\text { Reservoir } \\
\text { Inflow } \\
\text { (percent } \\
\text { change) }\end{array}$ & $\begin{array}{c}\text { Seco Creek } \\
\text { Reservoir } \\
\text { Outflow } \\
\text { (percent } \\
\text { change) }\end{array}$ & $\begin{array}{c}\text { Rowe } \\
\text { Ranch } \\
\text { (percent } \\
\text { change) }\end{array}$ & $\begin{array}{l}\text { Parkers } \\
\text { Creek } \\
\text { Reservoir } \\
\text { Inflow } \\
\text { (percent } \\
\text { change) }\end{array}$ & $\begin{array}{c}\text { Parkers } \\
\text { Creek } \\
\text { Reservoir } \\
\text { Outflow } \\
\text { (percent } \\
\text { change) }\end{array}$ \\
\hline Evapotranspiration & -5 & -5 & -5 & -5 & -6 & -5 \\
\hline Annual runoff & 27 & 6 & 1 & 18 & 47 & 2 \\
\hline Highest 10 percent of flows & 19 & 6 & 1 & 16 & 47 & 2 \\
\hline Lowest 50 percent of flows & 50 & 0 & 0 & 0 & 0 & 0 \\
\hline Volume of selected storms & 24 & 8 & 1 & 8 & 41 & 3 \\
\hline Interflow & 27 & 18 & 50 & 17 & 0 & 0 \\
\hline Surface runoff & 14 & 21 & 33 & 16 & 41 & 48 \\
\hline Summer flow volume & 18 & 4 & 0 & 33 & 85 & 13 \\
\hline Winter flow volume & 40 & 13 & 0 & 3 & 9 & 0 \\
\hline Summer storm volume & 10 & 3 & 0 & 24 & 200 & 13 \\
\hline
\end{tabular}

and channel losses had the most effect on storm and base-flow simulations (tables 5,6). The values for the parameters AGWS, LZS, and UZS represented the initial soil-moisture storage conditions at the start of the simulations (table 7). Changes in these values did have an effect on the model results early in a simulation period, but changes did not have an effect on model results more than 8 months into the simulation period.

\section{SIMULATION OF BEST-MANAGEMENT PRACTICES}

Alternative scenarios were developed to evaluate the potential effects of the primary BMPs of interest, which include brush management (removal of woody species) and weather modification (increased rainfall totals and rainfall intensities) on surface-water quantity in the upper Seco Creek Basin. Evaluation of a single BMP on a field scale was not possible because numerous BMPs at multiple sites were being implemented during the simulation period. Rather, the effect of all the BMPs were reflected in the final model parameter values. The following results of the scenarios provided an estimate of BMP effects. The alternative scenarios indicated a direction (increase or decrease) but not necessarily an accurate magnitude of the change.

\section{Brush Management}

The brush management BMP is the removal (treatment) of woody species (Juniperus ashei, locally known as cedar) and continued maintenance to eliminate the regrowth of the woody species. The rationale for the BMP is that by removing deep-rooted woody species, the ET potential in the basin will be reduced. Another study done in the upper Seco Creek Basin (Dugas and others, 1998) measured springflows downgradient of treatment areas and ET. After treatment, results indicated that discharge increased and that ET was reduced an average of about 0.003 in. per day.

In the Seco Creek at Miller Ranch subbasin, about 3,700 acres (12.8 percent of the subbasin) was treated by brush management (Phillip Wright, U.S. Department of Agriculture, Natural Resources Conservation Service, written commun., 2000). Other subbasins in the upper Seco Creek Basin had a minimal amount of woody species removed.

Simulation of woody-species treatment was approximated by reducing the values for the parameter LZETP by 20 percent. Simulation results are presented for all subbasins in table 10. Apparent large-percentage increases might not translate into substantial amounts of water if simulated volumes of water (table 8) were relatively small (in relation to other subbasins) prior to the simulation of LZETP reductions. Simulated results for the six subbasins indicated that reducing the values for 
Table 11. Simulation results from a 10-percent increase in rainfall totals and intensities associated with weather modification

\begin{tabular}{|c|c|c|c|c|c|c|}
\hline & $\begin{array}{c}\text { Miller } \\
\text { Ranch } \\
\text { (percent } \\
\text { change) }\end{array}$ & $\begin{array}{l}\text { Seco Creek } \\
\text { Reservoir } \\
\text { Inflow } \\
\text { (percent } \\
\text { change) }\end{array}$ & $\begin{array}{c}\text { Seco Creek } \\
\text { Reservoir } \\
\text { Outflow } \\
\text { (percent } \\
\text { change) }\end{array}$ & $\begin{array}{l}\text { Rowe } \\
\text { Ranch } \\
\text { (percent } \\
\text { change) }\end{array}$ & $\begin{array}{c}\text { Parkers } \\
\text { Creek } \\
\text { Reservoir } \\
\text { Inflow } \\
\text { (percent } \\
\text { change) }\end{array}$ & $\begin{array}{l}\text { Parkers } \\
\text { Creek } \\
\text { Reservoir } \\
\text { Outflow } \\
\text { (percent } \\
\text { change) }\end{array}$ \\
\hline Evapotranspiration & 6 & 6 & 6 & 6 & 5 & 6 \\
\hline Annual runoff & 32 & 10 & 2 & 48 & 92 & 9 \\
\hline Highest 10 percent of flows & 30 & 10 & 2 & 48 & 92 & 9 \\
\hline Lowest 50 percent of flows & 37 & 0 & 0 & 0 & 0 & 0 \\
\hline Volume of selected storms & 42 & 15 & 2 & 38 & 87 & 11 \\
\hline Interflow & 45 & 31 & 78 & 40 & 0 & 0 \\
\hline Surface runoff & 36 & 47 & 62 & 48 & 77 & 101 \\
\hline Summer flow volume & 23 & 6 & 0 & 62 & 115 & 13 \\
\hline Winter flow volume & 42 & 13 & 0 & 36 & 45 & 4 \\
\hline Summer storm volume & 33 & 7 & 0 & 55 & 189 & 13 \\
\hline
\end{tabular}

LZETP by 20 percent decreases simulated total ET by 5 to 6 percent.

The simulated increases in annual runoff and highest 10 percent of flows for the six subbasins ranged from 1 to 47 percent. The simulated lowest 50 percent of flows increased only at the Seco Creek at Miller Ranch subbasin because low flows do not occur frequently in the five other subbasins (table 8). Simulated volume of selected storms increased from 1 to 41 percent for the six subbasins; interflow ranged from no change to an increase of 50 percent; surface runoff increased from 14 to 48 percent. Simulated summer flow volume ranged from no change to an increase of 85 percent; winter flow volume ranged from no change to an increase of 40 percent; and summer storm volume ranged from no change to an increase of 200 percent.

The simulated annual runoff increased for all subbasins, but only the Seco Creek at Miller Ranch subbasin indicated increased base flow. Low flows in the Seco Creek at Miller Ranch, Seco Creek Reservoir Inflow, Seco Creek at Rowe Ranch, and Parkers Creek Reservoir Inflow subbasins are lost as channel losses to the Glen Rose Limestone of the Trinity aquifer, Leona Formation (a local shallow aquifer), and Devils River Formation of the Edwards aquifer. Very small changes in runoff were indicated in the Seco Creek Reservoir Outflow and Parkers Creek Reservoir Outflow subbasins because most of the flows in these subbasins were retained in Seco Creek Reservoir and Parkers Creek Reservoir, except those flows from large storms.

\section{Weather Modification}

Weather modification currently (2001) is being conducted by the Edwards Aquifer Authority (EAA) in the San Antonio region to enhance rainfall by seeding clouds in an effort to increase recharge to the Edwards aquifer (Edwards Aquifer Authority, 2001). Among the counties treated for rainfall enhancement are Bandera, Medina, and Uvalde, which encompass the Seco Creek Basin (fig. 1). According to the EAA, rainfall could be increased by about 10 to 20 percent.

A scenario to simulate increased rainfall was developed for the Seco Creek subbasins. Rainfall data (totals and intensities) were increased 10 percent for all six subbasins for every storm and for the entire simulation period. Simulations results are presented in table 11

A 10-percent increase in rainfall resulted in a 5- to 6-percent increase in ET for the six subbasins. The simulated annual runoff and the highest 10 percent of flows for the six subbasins increased from 2 to 92 percent. The simulated lowest 50 percent of flows increased only at the Seco Creek at Miller Ranch subbasin. Increased channel losses and ground-water recharge offset the increased precipitation in the other five subbasins. The simulated volume of selected storms increased from 2 to 87 percent; interflow ranged from no change to 
an increase of 78 percent; and total surface runoff increased 36 to 101 percent for the six subbasins. Simulated summer flow volume ranged from no change to an increase of 115 percent; winter flow volume ranged from no change to an increase of 45 percent; and summer storm volume ranged from no change to an increase of 189 percent.

Simulated results for the weather-modification scenario were comparable to the results for the brushmanagement scenario. The total runoff increased in all subbasins, but only base flow increased in the Seco Creek at Miller Ranch subbasin.

\section{SUMMARY}

The purpose of the study was to assess the effects of two best-management practices on selected hydrologic processes in the upper Seco Creek Basin, a primarily rangeland area of about $165 \mathrm{mi}^{2}$ that overlies parts of the Trinity and Edwards aquifers in south-central Texas. This report describes the development of a parameter set for use with a model (HSPF) to simulate flows in six gaged subbasins in the upper Seco Creek Basin and presents an assessment on the basis of simulation of the changes in surface-water quantity that could result from brush management (removal of woody species locally known as cedar) and weather modification (rainfall enhancement).

A model parameter set for use with HSPF was developed to simulate surface-water-budget components for six gaged subbasins. Rainfall and runoff data were collected during January 1, 1991September 30, 1998. Data from 60 storms were used for the simulations. Twenty-one pervious land segments were defined for the study on the basis of geology and land cover. Sixteen annual parameters, one monthly parameter, and three initial-condition parameters were defined for each land segment.

The model was calibrated with data from 33 storms (in two subbasins) and tested spatially with data from 27 storms (in four subbasins). The final parameter set was assumed to represent average subbasin conditions during the simulation periods. An error analysis and a sensitivity analysis were done on each subbasin, and the results were used to develop the final parameter set.

The calibrated and tested model was used to assess the effects of cedar removal and rainfall enhancement. Simulating the effects of cedar removal by decreasing ET 5 to 6 percent resulted in simulated increases in annual runoff of 1 to 47 percent and increases in surface runoff of 14 to 48 percent. Simulated increases in rainfall totals and intensities of 10 percent from weather modification yielded increases of 5 to 6 percent in ET, increases in annual runoff of 2 to 92 percent, and increases in surface runoff of 36 to 101 percent for the six subbasins.

\section{REFERENCES}

Bicknell, B.R., Imhoff, J.C., Kittle Jr., J.L., Donigian, A.S., Jr., and Johanson, R.C., 1997, Hydrological Simulation Program-FORTRAN, user's manual for version 11: Athens, Ga., U.S. Environmental Protection Agency, National Exposure Research Laboratory, EPA/600/R-97/080, $755 \mathrm{p}$.

Brown, D.S., Mosier, J.G., and Nalley, G.M., 1999, Geologic framework and hydrogeologic properties of the Seco Creek watershed, Texas: U.S. Geological Survey Fact Sheet FS-104-98, 4 p.

Chow, V.T., Maidment, D.R., and Mays, L.W., 1988, Applied hydrology: New York, McGraw-Hill, 572 p.

Dugas, W.A, Hicks, R.A., and Wright, P., 1998, Effect of removal of Juniperus ashei on evapotranspiration and runoff in the Seco Creek watershed: Water Resources Research, v. 34, no. 6, p. 1,499-1,506.

Edwards Aquifer Authority, 2001, Precipitation enhancement program, 2001: Accessed November 26, 2001, at URL http://www.edwardsaquifer.org/Pages/theprograms/ precip_description.html

Hydrosphere, 2000, Climate data-A computer program and climatic database; NCDC summary of the day-West 2: National Climatic Data Center, v. 11.3.

Lumb, A.M., McCammon, R.B., and Kittle, J.L., Jr., 1994, Users manual for an expert system (HSPEXP) for calibration of the Hydrological Simulation ProgramFORTRAN: U.S. Geological Survey Water-Resources Investigations Report 94-4168, 102 p.

Maidment, D.R., 1993, Handbook of hydrology: New York, McGraw-Hill, 1,424 p.

Shearman, J.O., 1990, Users manual for WSPRO-A model for Water Surface PROfile computations (hydraulic computer program HY-7): U.S. Department of Transportation, Federal Highway Administration, Publication FHWA-IP-89-027, 187 p.

Small, T.A., and Clark, A.K., 2000, Geologic framework and hydrogeologic characteristics of the Edwards aquifer outcrop, Medina County, Texas: U.S. Geological Survey Water-Resources Investigations Report 00-4195, 10 p.

Steffens, Tim, and Wright, Phillip, 1995, Seco Creek WaterQuality Demonstration Project, annual project report fiscal year 1995: U.S. Department of Agriculture, Natural Resources Conservation Service, 254 p. 
District Chief

U.S. Geological Survey

8027 Exchange Dr.

Austin, TX 78754-4733 